\title{
Crustal Architecture of the Inverted Central Lapland Rift Along the HUKKA 2007 Profile
}

\author{
Timo Titra, ${ }^{1}$ Tomasz Janik, ${ }^{2}$ Elena Kozlovskaya, ${ }^{3}$ Marek Grad, ${ }^{4}$ Annakaisa Korja, ${ }^{1}$ Kari Komminaho, ${ }^{1}$ \\ Endre Hegedüs, ${ }^{5}$ Csaba Attila Kovács, ${ }^{5}$ Hanna Silvennoinen, ${ }^{3}$ and Ewald BrückL ${ }^{6}$
}

\begin{abstract}
We have studied the lateral velocity variations along a partly buried inverted paleo-rift in Central Lapland, Northern Europe with a 2D wide-angle reflection and refraction experiment, HUKKA 2007. The experiment was designed to use seven chemical explosions from commercial and military sites as sources of seismic energy. The shots were recorded by 102 stations with an average spacing of $3.45 \mathrm{~km}$. Two-dimensional crustal models of variations in $\mathrm{P}$-wave velocity and $\mathrm{Vp} / \mathrm{Vs}$-ratio were calculated using the ray tracing forward modeling technique. The HUKKA 2007 experiment comprises a $455 \mathrm{~km}$ long profile that runs NNWSSE parallel to the Kittilä Shear Zone, a major deformation zone hosting gold deposits in the area. The profile crosses Paleoproterozoic and reactivated Archean terranes of Central Lapland. The velocity model shows a significant difference in crustal velocity structure between the northern (distances 0-120 km) and southern parts of the profile. The difference in P-wave velocities and $\mathrm{Vp} / \mathrm{Vs}$ ratio can be followed through the whole crust down to the Moho boundary indicating major tectonic boundaries. Upper crustal velocities seem to vary with the terranes/compositional differences mapped at the surface. The lower layer of the upper crust displays velocities of $6.0-6.1 \mathrm{~km} / \mathrm{s}$. Both Paleoproterozoic and Archean terranes are associated with high velocity bodies $(6.30-6.35 \mathrm{~km} / \mathrm{s})$ at 100 and $200-350 \mathrm{~km}$ distances. The Central Lapland greenstone belt and Central Lapland Granitoid complex are associated with a $4 \mathrm{~km}$-thick zone of unusually low velocities $(<6.0 \mathrm{~km} / \mathrm{s})$ at distances between 120 and $220 \mathrm{~km}$. We interpret the HUKKA 2007 profile to image an old, partly buried, inverted continental rift zone that has been closed and modified by younger tectonic events. It has structural features typical of rifts: inward dipping rift shoulders, undulating thickness of the middle crust, high velocity lower crust and a rather uniform crustal thickness of $48 \mathrm{~km}$.
\end{abstract}

1 Department of Geosciences and Geography, University of Helsinki, POB 68, 90014 Helsinki, Finland. E-mail: timo.tiira@helsinki.fi

2 Institute of Geophysics, Polish Academy of Sciences, Ks. Janusza 64, 01-452 Warsaw, Poland.

3 Sodankylä Geophysical Observatory/Oulu Unit, University of Oulu, POB 3000, 90014 Oulu, Finland.

4 Institute of Geophysics, Faculty of Physics, University of Warsaw, Pasteura 7, 02-093 Warsaw, Poland.

5 Eötvös Loránd Geophysical Institute of Hungary, 1445 Budapest, Hungary.

6 Institute of Geodesy and Geophysics, Vienna University of Technology, Gusshausstrasse 27-29/1282, 1040 Vienna, Austria.
Key words: Rift, crust, upper mantle, Vp, Vp/Vs ratio, Fennoscandia, Central Lapland, Greenstone belt.

\section{Introduction}

One of the driving mechanisms of continental evolution is the assembly and dispersal of supercontinents (BRADLEY 2011). In addition to plate tectonic forces, mantle plumes drive supercontinent dispersal. When a continental plate is placed above a mantle plume, it will be thermally uplifted leading to spreading and thinning of the continental lithosphere. The plume not only leaves traceable geological markers such as wide spread mafic magmatism (continental large igneous provinces (LIPs); ERNST and BUCHAN 2001) and coeval sedimentary basins but also geophysical markers such as thinner crust, high velocity lower crust and high velocity bodies in the upper crust (CoFfin and Eldholm 1993; BehrendT et al. 1988; Keranen et al. 2004). Together with the stretched crustal remnants and the fresh magmatic additions, a new stable continental lithosphere is formed either in intracratonic rifts or at passive margins.

Crust that forms or that is deformed under extension is stabilized due to strain hardening (KUSZNIR and PARK 1987) and thus it will be hard to break such crust in later tectonic processes. This has been well documented in failed rifts/aulacogens (Midcontinent rift; BEHRENDT et al. 1988) as well as in thrust belts where rifted margins have been stacked back on the extended continent e.g. Appalachians (COCORP; COOK et al. 1981), Alps (TRANSALP; BERGE and VEAL 2005). In both tectonic environments, compression not only fails to ignore the old block 
boundaries but rather reactivates them in inverted structures. It must be noted that the reactivated structures are likely to have different slip directions during each extensional or compression episode.

Before continents break, plate tectonic forces are rearranged to accommodate for the emerging new plate boundaries and triple points. The break-up is preceded by extensional tectonics, basin formation and rift related magmatism, the result of which we may observe only on the continental parts of the rift zone. The appearance of the rift relies on the geometry of the extensional process as well as on the source of mantle magmatism. In rift zones, where simple shear stress is dominant, the opposing sides of the rift are asymmetric with slightly different sedimentary and magmatic histories (LISTER et al. 1986). The upper plate comprises shallower lithologies that were originally above the detachment zone whereas the lower plate displays deeper units that were originally below the detachment. Changes from the upper to the lower plate geometries may take place over transfer faults. Changes from upper plate to lower plate geometries are likely to take place within one rift arm, leading to changing extensional environments along the rift. All the rift arms from one triple point are not likely to evolve at similar speed or reach the same extensional stage: failed rift, rift, and passive margin.

The Central Lapland Greenstone Belt (CLGB) is a well-known large igneous province $(2.5-2.0 \mathrm{Ga})$ at the northwestern edge of the Fennoscandian Shield in Northern Europe (Fig. 1; Amelin et al. 1995; Heaman 1997; SORJONEN-WARD et al. 1997; ERnSt and BuChan 2001; Hanski and Huhma 2005; Melezhik 2006). The northern part of the Shield is a collage of Archean and Paleoproterozoic terranes that were accreted in the Svecofennian and Lapland-Kola orogenies approximately 1.9-1.8 Ga ago (GoRBATSCHEV and Bogdanova 1993; Daly et al. 2006; KorJa et al. 2006). The majority of the collisional terrane boundaries are in NW-SE direction. In Central Lapland, however, the change from Archean to Paleoproterozoic lithologies is more complex resulting in additional boundaries in NE-SW and N-S directions. It is an area where both Archean and Paleoproterozoic terranes either halt or intertwine with each other and where the lithologies are dominated by rift related volcano-sedimentary sequences (DALY et al. 2006; Korja et al. 2006; SLABUnov et al. 2006). The area is also transected by NW-SE-directed strike slip faults (Sirkka Line/Kittilä Shear Zone (KSZ), Meltaus Shear zone (MSZ); GaÁl et al. 1989; PATISON et al. 2006; KORJA and HeIKKINEN 2008).

A terrane is defined as a fault-bounded package of rocks characterized by a distinct geologic history that differs from the neighbouring ones. Recently, READING (2005) and BogDANOva et al. (2006) demonstrated that the depth to the seismic Moho, the velocity contrast at the Moho boundary, the velocity profile of the crust and the seismic velocity of the upper mantle may be used to identify geological terranes and to trace their tectonic boundaries. Previous seismic surveys in the Baltic Shield have revealed a thick crust with large thickness variations ranging from 40 to $65 \mathrm{~km}$ (GRAD et al. 2009), that have been associated with major tectonic events (KORJA et al. 1993). Central Lapland has rather low and uniform Moho depth values (Fig. 2) suggesting a different tectonic environment from the accretionary orogen of southern and central Finland. The area hosts minor Moho depressions with enigmatic origins.

The majority of the deep seismic sounding (DSS) and reflection profiles have focused on transecting the compressional structures at the terrane boundaries in a NE-SW direction (Fig. 2; POLAR, SVEKA81, BALTIC, FIRE1, FIRE4) or revealing the internal architecture of the Archean (EU1, 4B, KostomukshaPechenga) or Paleoproterozoic (EGT/FENNOLORA, FINLAP7) (Luosto et al. 1990; GugGisberg et al. 1991; Sharov 1993; Mints et al. 2004a; MinTs et al. 2004b; Grad and Luosto 1987; Luosto et al. 1989; KuKKonen et al. 2006; PATISON et al. 2006; JANiK et al. 2009). Nevertheless, neither the lateral change along the strike of the terranes nor the more gradual NW-SE change from Archean to Paleoproterozoic dominated areas, is well understood. Another reason for warranting a cross-line DSS profile in this region is the large mineral exploration potential ( $\mathrm{Au}, \mathrm{Cu}, \mathrm{Cr}, \mathrm{PGE}$ ) of one of the fastest growing mining areas of Europe.

With the help of a seismic refraction and wideangle reflection profile, HUKKA 2007, we will study the three dimensional crustal structure of the Central Lapland Greenstone Belt and the NW-SE transition from Archean to Paleoproterozoic terranes. We will 


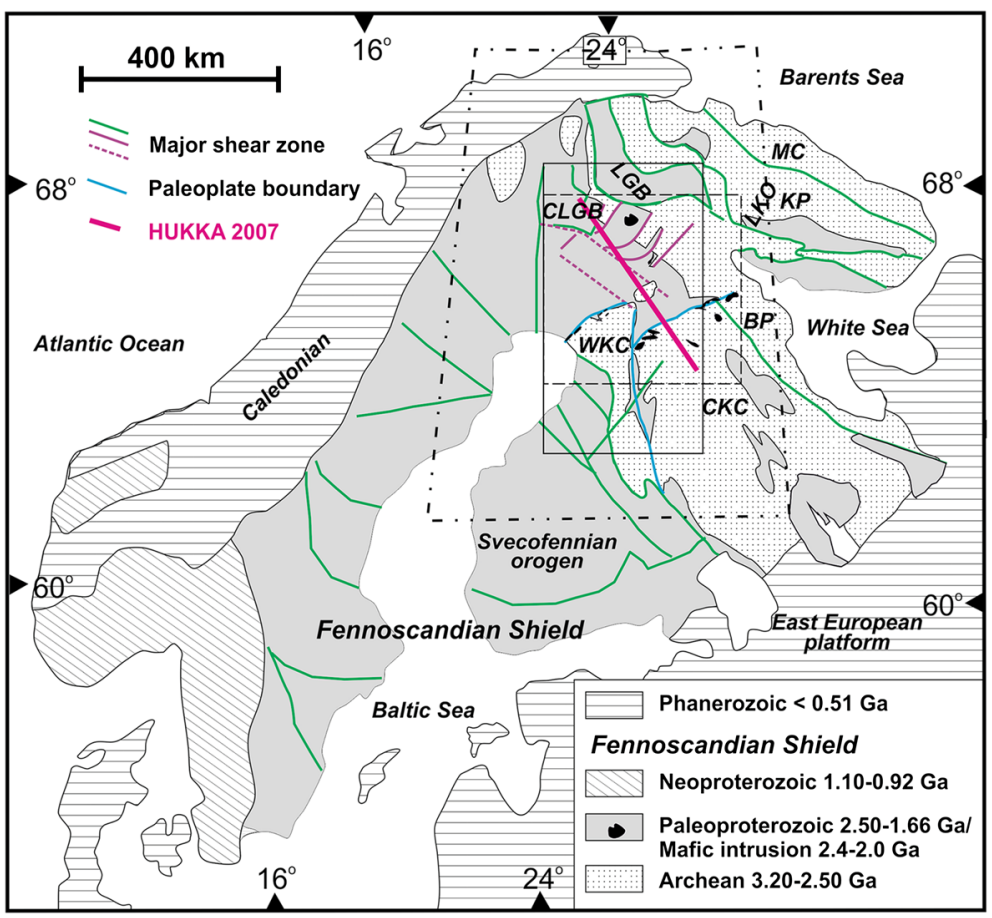

Figure 1

The HUKKA 2007 profile on a tectonic framework map of the Fennoscandian Shield modified after KoRJA et al. (2006). The large box with the dash-dotted line shows the location of Fig. 2, the box with the solid black line shows the location of Fig. 3 and the small square with the dashed line shows the location of Fig. 13b. Abbreviations: BP Belomorian Province, $C K C$ Central Karelian craton, CLGB Central Lapland greenstone belt, $K P$ Kola province, $L G B$ Lapland granulite belt, $L K O$ Lapland Kola Orogen, $M C$ Murmansk craton, $W K C$ Western Karelian craton

compare P-velocity, S-velocity and $\mathrm{Vp} / \mathrm{Vs}$-ratio crustal and mantle models with the existing terrane models at the surface. We will show that the Central Lapland rift was spreading in NW-SE direction and that crustal structure is characterized by an inverted Paleoproterozoic continental rift structure overlain by younger thrust sheets.

\section{Geological and Geophysical Setting}

The northern Fennoscandian Shield has a complex tectonic evolution. The Shield comprises Archean and Paleoproterozoic terranes that were merged during the Svecofennian and Lapland-Kola orogenies at $1.9 \mathrm{Ga}$ ago (Gorbatschev and Bogdanova 1993; DAly et al. 2006; KoRJA et al. 2006). Minor adjustments have taken place during Mesoproterozoic and Phanerozoic as responses to continental growth taking place at remote plate margins. The study area hosts the eastern Archean [Western Karelian craton (WKC), the Central Karelian craton (CKC), Belomorian Province (BP)] and western Paleoproterozoic terranes [CLGB, the Central Lapland Granitoid complex (CLGC), Kittilä allochthon (KA), and the Kuusamo belt (KuB)].

The Archean terranes (WKC, CKC, BP) formed between 3.7 and $2.7 \mathrm{Ga}$ and were welded together in Neoarchean collisions at $2.9 \mathrm{Ga}$ (Slabunov et al. 2006). As a response to a mantle plume, the Neoarchean orogenic domain rifted at the beginning of the Paleoproterozoic Era (AMELIN et al. 1995; HeAman 1997; SorJonen-Ward et al. 1997; Hanski and HuHMa 2005; Melezhik 2006; Lahtinen et al. 2008). Several rift basins and/or rifted margins [e.g., CLGB, KuB, Peräpohja belt (PB), Lapland granulite belt (LGB)] developed in the west, northwest and north. A subsequent compressional phase (Lapland-Savo and Lapland-Kola orogenies) involved the extended Archean terranes as well as Paleoproterozoic rift 


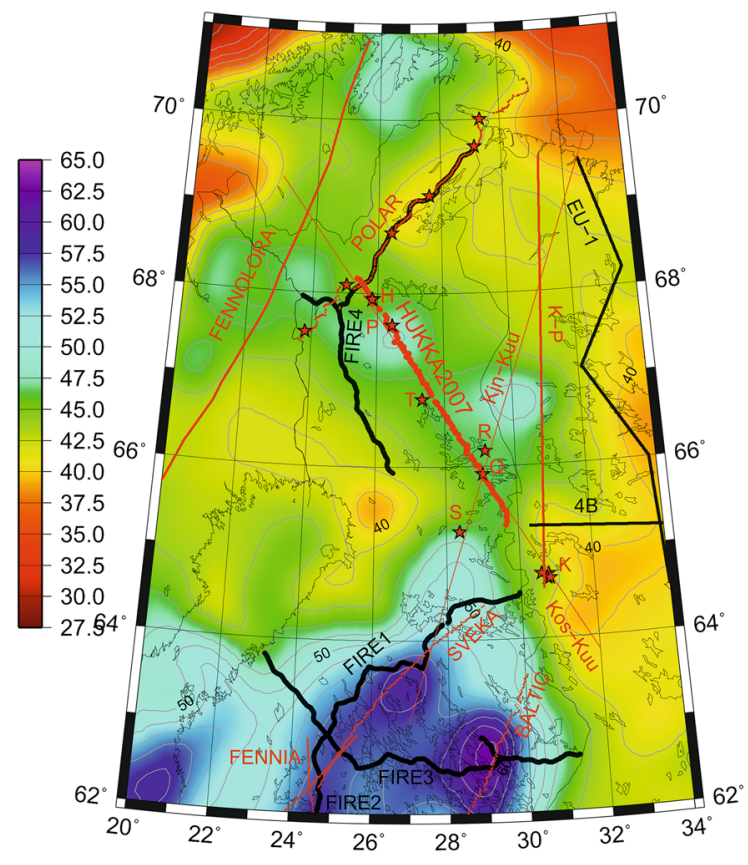

Figure 2

A Moho map of Central Lapland modified from GRAD et al. (2009). Results of this study are included in the compilation. Refraction profiles are in red and reflection profiles in black. The small and uniform Moho depth values of the Northern Fennoscandian Shield indicate a different tectonic evolution from the deep southern parts. Structural trend is NW-SE

basins, oceanic arcs, continental arcs and basins (Korja et al. 2006; Daly et al. 2006; LAhtinen et al. 2008). The western terranes (KA) thrust east-southeast on the rifted margin (CLGB) in the Lapland-Savo orogeny. Subsequently, also the basins in the north east closed in the Lapland-Kola orogenic phase. This resulted, e.g., in a west-southwestward thrusting of LGB. The Belomorian terrane especially suffered from large scale reworking and exhumation in the Lapland-Kola orogeny (SLABunOv et al. 2006; HöLtTÄ et al. 2008).

The newly formed Lapland-Savo-Kola orogenic domain was involved in yet another accretion, when the Svecofennian domain docked to its south-southwest margin. This resulted in $\mathrm{N}-\mathrm{S}$ compression, the closure of southern basins ( $\mathrm{PB}, \mathrm{KuB})$, the thrusting of the allochthonous units (CLGC) and the thickening of the crust in Central Lapland. The orogenic structures were rearranged during collapse phases (LAHTINEN et al. 2005; KoRJA et al. 2006). The collapse probably induced the exhumation of the LGB (PATISON et al.
2006; TuIsku and Huhma 2006), the emplacement of the variety of granitoids in the CLGC (Evins et al. 2002; Ahtonen et al. 2007), the development of large scale normal faults along existing faults (e.g., the KSZ) and the deposition of the Kumpu molasse sediments in normal fault bounded basins.

The Neoarchean terranes comprise TTG (tonalitetrondhjemite-granodiorite) granitoid series and migmatites as well as remnants of greenstone belts. The terranes are intruded by mafic dyke swarms and layered intrusions associated with Paleoproterozoic rifting events. The extended Neoarchean crust forms the basement to the autochthonous and para-autochthonous Paleoproterozoic volcano-sedimentary belts (CLGB, KUB, PB). The belts comprise volcanosedimentary rocks, mafic dykes and layered intrusions that have been deposited in and intruded at intracratonic rift and passive margin environments (Fig. 3; Korsman et al. 1997). The southwestern edge of the CLGB hosts a large scale dextral shear zone called the Sirkka Line (GAÁl et al. 1989) or KSZ (PAtison et al. 2006). The KA (>1.92 Ga) comprises volcano-sedimentary remnants of an oceanic island arc and an ophiolitic rim. The allochthon has been obducted on the para-autochthonous passive margin terranes of the CLGB from the west-northwest and later intruded by post collisional granites (HANSKI and HuHMa 2005).

The Paleoproterozoic CLGC comprises a collage of migmatitic gneisses, Neoarchean basement nappes (e.g., Suomu complex (SC)) and intruding granites (Evins et al. 2002; Ahtonen et al. 2007). The FIRE4 reflection profile suggests that the CLGC is a thin thrust sheet on top of previously deformed units (PAtison et al. 2006). The granitoids have inherited Archean zircons indicating an Archean crustal source at depth (Ahtonen et al. 2007). The complex shows repeated tectonic and magmatic activity between 2.1 and $1.82 \mathrm{Ga}$ (AHTONEN et al. 2007) associated with sequential extensional and compressional events. The eastern part of the CLGC is separated from the main complex by the NW-SE running Ailanka shear zone (ASZ), a parallel shear zone to the KSZ. The CLGC is transected by a wealth of NW-SE directed shear zones, the most notable being the crustal scale Meltaus shear zone (MSZ) (PATISON et al. 2006). 


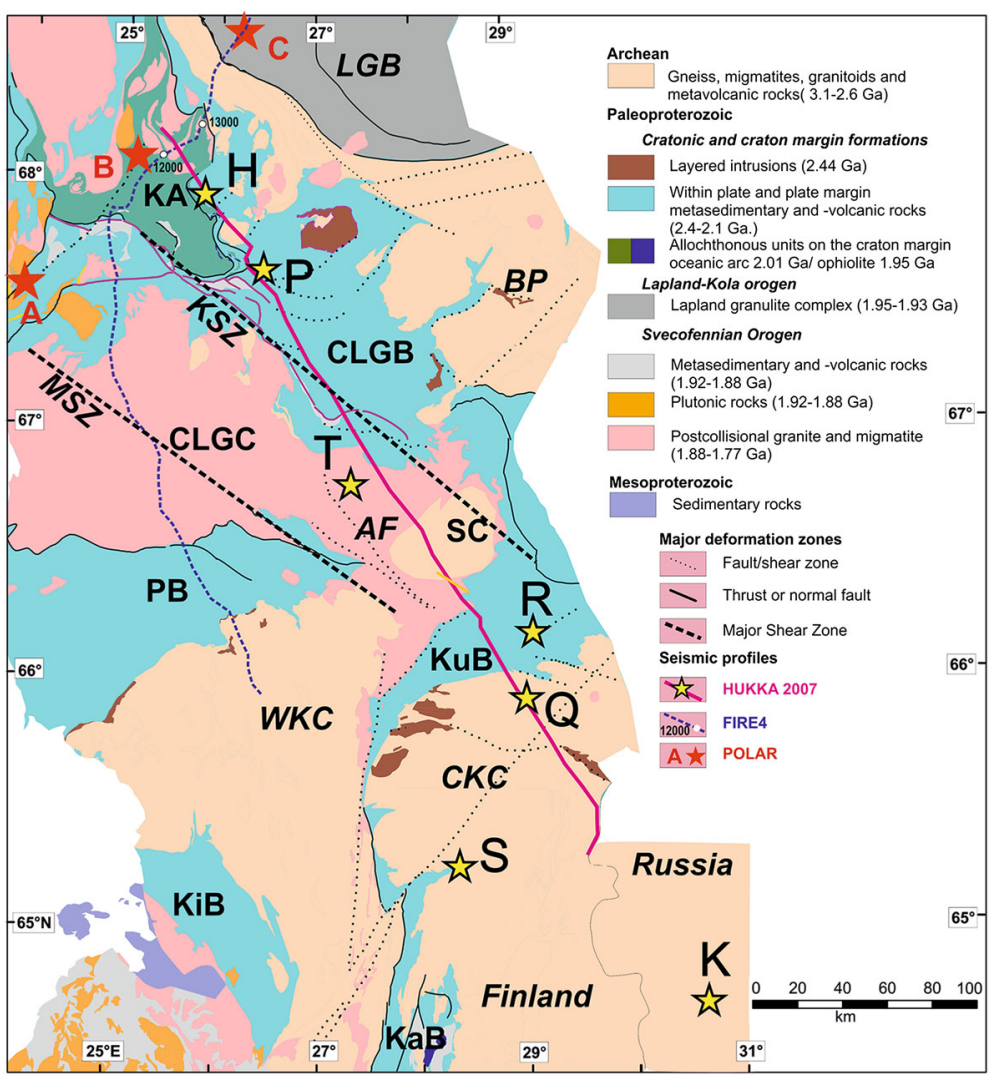

Figure 3

The HUKKA 2007 profile on the lithological map of Central Lapland, Northern Finland after KonSMAN et al. (1997). Major shear zones are after Patison et al. (2006). Stars and letters denote the shot points ( $H$ Hukkavaara, $P$ Pahtavaara, $T$ Tohmo, $R$ Ruka, $Q$ Kuusamo, $S$ Suomussalmi, and $K$ Kostomuksha). Abbreviations: $B P$ Belomorian Province, $C K C$ Central Karelian craton, $C L G B$ Central Lapland greenstone belt, $C L G C$ Central Lapland granitoid complex, $K A$ Kittilä allochthon, $K a B$ Kainuu Belt, KiB Kiiminki belt, $K u B$ Kuusamo belt, $L G B$ Lapland granulite belt, $P B$ Peräpohja Belt, $S C$ Suomu complex, $W K C$ Western Karelian craton. Shear zones: $A F$ Ailanka fault zone, $K S Z$ Kittilä shear Zone, MSZ Meltaus shear Zone

\section{Data Acquisition}

The HUKKA 2007 profile is a $455 \mathrm{~km}$ long DSS profile in the northern Fennoscandian Shield (Fig. 1). The profile runs NNW-SSE from Kittilä, Central Lapland, Finland to Kostomuksha, Karelia, NW Russia. HUKKA 2007 is a low cost DSS profile using seven commercial and military chemical explosion sites as sources of seismic energy and, thus, as shot points (Table 1; Fig. 3). The two largest sources of seismic energy (SP H and SP K; Fig. 3) are located near the ends of the profile. At shot point $\mathrm{H}$ (SP HHukkavaara hill) the Finnish Army destroys old explosive materials. In August and September 2007, a grand total of 55 explosions were shot at Hukkavaara. The amount of explosive material varied between
19,770 and $28,440 \mathrm{~kg}$. SP K is located at the Russian Kostamuksha (see Fig. 3) iron quarry, where explosions of several tons of explosive materials are made a few times per week. Other quarries using detectable amounts of explosives, and located up to $14 \mathrm{~km}$ from the line of the profile, are utilized as additional sources (Table 1). However, SP S is located ca. $65 \mathrm{~km}$ off-line. For shot points R, S and K, the shot sizes were not known.

The experiment was carried out in August of 2007 by the Institute of Seismology, University of Helsinki. The portable seismometers and field staff were provided by the Institute of Geophysics, Polish Academy of Sciences, Sodankylä Geophysical Observatory, University of Oulu, Eötvös Loránd Geophysical Institute of Hungary, Institute of 
Table 1

Shot point information

\begin{tabular}{lrrrrr}
\hline $\begin{array}{l}\text { Shot } \\
\text { point }\end{array}$ & Latitude & Longitude & Size (kg) & $\begin{array}{l}\text { Distance } \\
\text { along profile } \\
(\mathrm{km})\end{array}$ & $\begin{array}{l}\text { Distance } \\
\text { off line } \\
(\mathrm{km})\end{array}$ \\
\hline $\mathrm{H}$ & $67.934^{\circ}$ & $25.829^{\circ}$ & $\sim 22,000$ & 33.094 & 0.205 \\
$\mathrm{P}$ & $67.637^{\circ}$ & $26.453^{\circ}$ & $\sim 8,000$ & 75.329 & 3.889 \\
$\mathrm{~T}$ & $66.776^{\circ}$ & $27.354^{\circ}$ & $\sim 7,000$ & 177.071 & -14.264 \\
$\mathrm{R}$ & $66.177^{\circ}$ & $29.145^{\circ}$ & & 275.581 & 18.825 \\
$\mathrm{Q}$ & $65.913^{\circ}$ & $29.061^{\circ}$ & $\sim 5,000$ & 298.190 & 1.195 \\
$\mathrm{~S}$ & $65.247^{\circ}$ & $28.373^{\circ}$ & & 351.172 & -62.111 \\
$\mathrm{~K}$ & $64.746^{\circ}$ & $30.569^{\circ}$ & & 445.509 & -1.126 \\
\hline
\end{tabular}

The size of the shots at $R, S$ and $K$ is not known. At shot point $H$ the size varied between 19,770 and $28,440 \mathrm{~kg}$. The average was $21,905 \mathrm{~kg}$. The other information on SP $H$ is for shot 17 for which stacking was done. For SP $K$ information is for the shot with best SNR. Distances are computed from the beginning of the profile and offsets are positive to the northeast of the profile

$H$ Hukkavaara (five record sections and the sixth stacked), $P$ Pahtavaara, $T$ Tohmo, $R$ Ruka, $Q$ Kuusamo, $S$ Suomussalmi, $K$ Kostomuksha

Geodesy and Geophysics, Vienna University of Technology and Institute of Seismology, University of Helsinki. The shots were recorded by 98 portable recording stations deployed along the profile and by four permanent seismic stations. The average station spacing was $3.45 \mathrm{~km}$. The profile was extended $33 \mathrm{~km}$ to the NNW from SP H, to cross with the preexisting POLAR profile (see Fig. 2). The seismometers were deployed only in Finland and, thus, there are no records closer than $75 \mathrm{~km}$ to SP K. Due to the road infrastructure, the locations of the stations are offset from the ideal line geometry. The maximum offset is $14 \mathrm{~km}$, the average is $1.3 \mathrm{~km}$ and the median offset is $0.68 \mathrm{~km}$.

The measurements were made using 98 portable seismic stations, two permanent broad-band seismic stations maintained by the University of Oulu and two semi-permanent short period stations of the Kuusamo network (UsKi et al. 2012) maintained by the University of Helsinki. The portable seismic stations were equipped with short period seismometers or $4.5 \mathrm{~Hz}$ geophones. The recording devices of the portable stations included 1-component Reftek-125 recorders (80 units) and 3-component recorders (17 units) from the Eötvös Loránd Geophysical Institute of Hungary. In addition, one Reftek 130 recorder was used. The exact shot times were not known and thus the recording windows were longer than usually used in active seismic experiments. Due to memory limitations on most of the stations, the sampling rate was set to $50 \mathrm{~Hz}$.

\section{Data Processing}

Locations of the shots were measured using GPS when possible. The locations of the 55 Hukkavaara shots were defined by the military personnel with GPS. These were situated within an area with a diameter of $<330 \mathrm{~m}$. The locations of shots $\mathrm{R}$ and $\mathrm{S}$, of which there was not prior knowledge, and of shot $\mathrm{K}$ in Kostomuksha could not be measured on site. Origin time estimation for events with locations measured with GPS was done using first $\mathrm{P}$ wave onsets at the closest stations. The number of the stations, which were used, depended on the quality of the data recorded at the stations. The signal onsets from the 3-5 closest stations to the shot point in both directions along the line were picked. These signals were also correlated with each other to refine the picks. The resulting $\mathrm{P}$ wave arrival picks were used to compute the near surface $\mathrm{P}$ wave velocity for the shot point. The origin time was computed using distances between the SP and the stations, the pick times and the near surface $P$ wave velocity.

Origin times and locations of the shots $\mathrm{R}, \mathrm{S}$ and $\mathrm{K}$ were defined using first $\mathrm{P}$ and $\mathrm{S}$ wave arrival picks and a location routine. The explosions were located by fixing the depth to zero. A weighted least squares inversion algorithm for refracted $\mathrm{P}$ and $\mathrm{S}$ waves was used for event location. Recordings of stations of the Finnish permanent seismic network, Kuusamo network and HUKKA 2007 profile were used to compute locations. A 1D velocity model (USKI et al. 2012) was used in computing the locations. We utilized data at epicentral distances $<250 \mathrm{~km}$, in order to minimize errors resulting from the use of a 1D velocity model and from the large variation of the Moho depth. The diameter of the Kostomuksha quarry area is about $8 \mathrm{~km}$. The obtained locations for SP K lie within this area.

The major source of inaccuracy in earthquake locations in this case is the azimuthal gap in station distribution since station event distances and signal 
qualities are comparable. The azimuthal gap should be below $180^{\circ}$ to yield accurate locations. For SP K it is $189^{\circ}$, and for SP R and SP S it is $88^{\circ}$ and $93^{\circ}$, respectively. UsKi et al. (2012) concluded that location accuracy in the Kuusamo region is 1-2 km if the azimuthal gap is $<160^{\circ}$ and the epicentral distances to stations used in the location are $<250 \mathrm{~km}$. The location inaccuracy for SP R and SP S is estimated to be similar or slightly better due to the larger amount of stations within a short distance from the source. For SP K, the location inaccuracy might be slightly more than $1-2 \mathrm{~km}$ due to the larger azimuthal gap.

The field recordings were cut to a length of $100 \mathrm{~s}$ starting at $-5 \mathrm{~s}$ in reduced time and sorted into shot gathers. The cut traces were trace-normalized to the maximum amplitude of each trace. They were plotted with a reduction velocity of $8 \mathrm{~km} \mathrm{~s}^{-1}$, which is the upper mantle velocity commonly used for data visualization in crustal/upper mantle studies. For plotting, the seismic sections were cleaned from noisy traces. Examples of the recorded wave fields are shown in Figs. 4, 5, 6, 7, 8, 9 and 10.

Data from shot point $\mathrm{H}$ were stacked in order to improve the signal to noise ratio. The number of shots which were stacked varied between stations because limited memory capacity forced us to limit the number and length of recording windows at many stations. The average number of stacked shots was 20. Data quality was checked and data with excess noise or other problems were weeded out before stacking. The locations of the shots were known with an accuracy of $5 \mathrm{~m}$ and the time errors between origin times were estimated to be less than one sample by cross-correlating signals at the closest stations. The stacked record section and five unstacked record sections of SP H are shown in Fig. 5. The stacking increased the signal to noise ratio especially at distances above $300 \mathrm{~km}$, and it was easier to identify Pn and $\mathrm{Sn}$ phases as well as reflected phases.

In shots $\mathrm{P}, \mathrm{T}$ and $\mathrm{Q}$ and most probably also shots $\mathrm{R}, \mathrm{S}$, and $\mathrm{K}$ a delayed shooting technique was used. This affects the transfer of the energy into seismic waves. The longer spread in initial shooting times results in longer source time and signals. This leads to lower resolution in the later seismic wave phases in the recording sections.

\section{5. $P$ - and $S$-Wave Field}

The data quality of the seismic records is variable and depends on source type and size. Band-pass filters of 2-12 Hz for P-wave seismograms and 1-9 Hz for both S-wave and P-wave and S-wave seismograms have been applied to the data (Fig. $4 \mathrm{a}-\mathrm{c}$ ). $\mathrm{S}$-waves are detected on most vertical component record sections (Fig. $4 \mathrm{a}-\mathrm{c}$ ). The best quality of data was observed from shot points $\mathrm{H}-$ Hukkavaara, $\mathrm{P}$ Pahtavaara, T-Tohmo, Q-Kuusamo, and $\mathrm{K}$ Kostomuksha (two record sections). The record section of shot point $\mathrm{R}$ - Ruka showed less energy and shot point S-Suomussalmi was about $60 \mathrm{~km}$ off line.

\subsection{Pg and $\mathrm{Sg}$ Phases}

The P-wave refracted from the crust that appears as the first arrival $(\mathrm{Pg})$ has rather consistently high apparent velocities varying from ca. 6.25 to $6.7 \mathrm{~km} / \mathrm{s}$ at offsets from 60 to $150-220 \mathrm{~km}$ on the record sections along the whole profile. The range of clear $\mathrm{Pg}$ onsets depends strongly on the quality of the record section, which, in turn, depends on charge and "seismic quality" of the shot. Sometimes, the first arrivals are possible to identify up to offsets of 60-70 km only, see for example, SP T (NW direction) (Fig. 9) or SP R (SE direction) (Fig. 6). For larger offsets the first arrivals are not visible in the background of noise, which is relatively high compared to record sections from other DSS experiments in Finland, e.g., SVEKA, POLAR, BALTIC and other profiles. There can be several reasons for this. Firstly, all the recordings were made during the day time along the HUKKA 2007 profile and at night time with other profiles. The second reason can be the geometry of the blasting areas (wide areas, location on the hill, etc.), which resulted in less effective excitation of seismic energy. It could be also an expression of existing 'shadow zones' as a result the of occurrence of low velocity zones (LVZ) in the crust. Apparent velocities slightly higher than $7 \mathrm{~km} / \mathrm{s}$ are seen on record sections of SP $\mathrm{H}$ and SP K $(7.0-7.05 \mathrm{~km} / \mathrm{s})$, at offsets from 205 up to $215 \mathrm{~km}$ (Figs. 7, 10). 

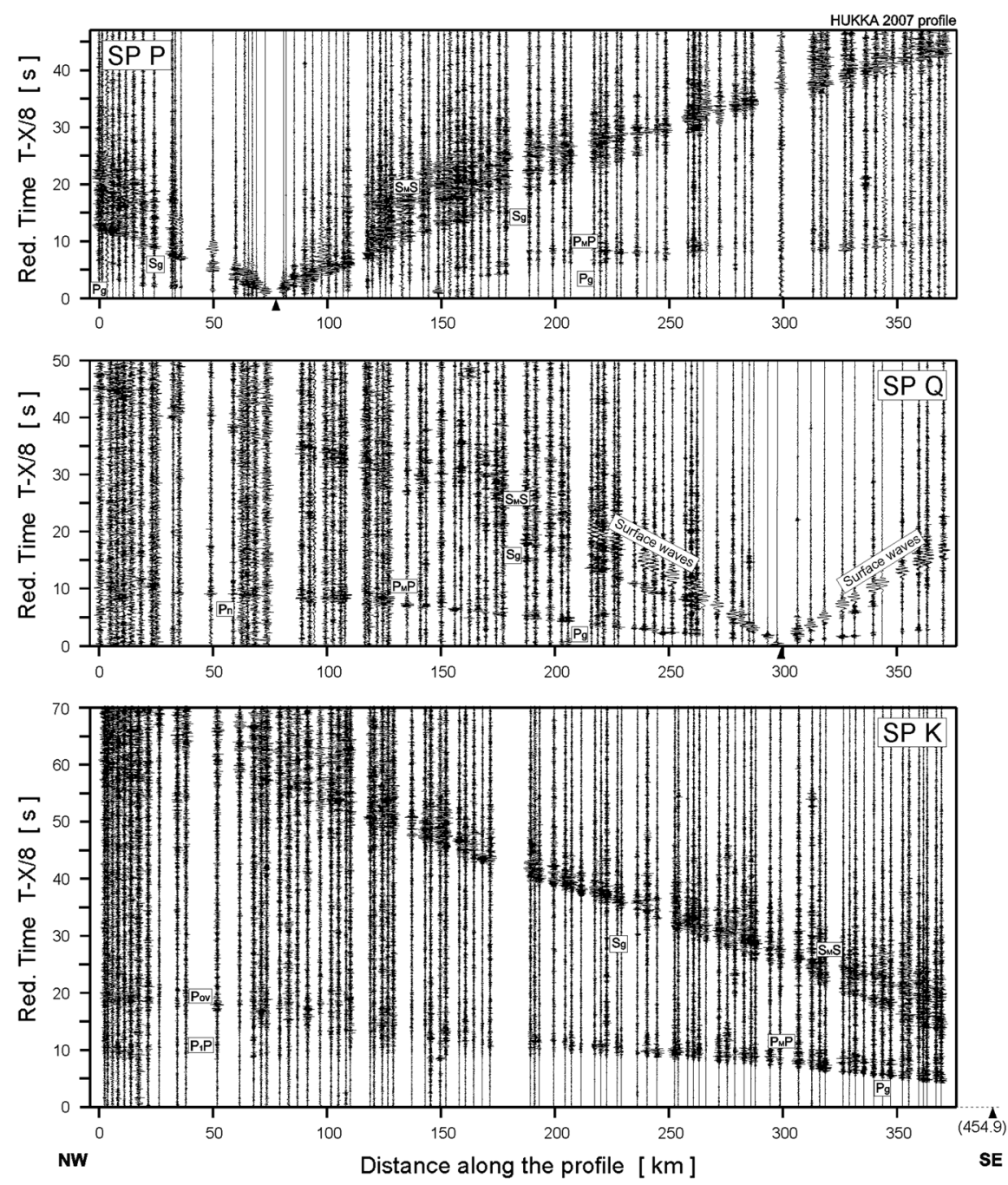

Figure 4

Examples of trace-normalized, vertical-component common seismic record sections for $\mathrm{P}$ and $\mathrm{S}$ waves along the HUKKA 2007 profile (SP P, SP Q and SP K). Record sections are band-pass filtered (2-12 Hz). Explanations: $P g$, $S g$ seismic refractions from the upper and middle crystalline crust, $P_{O V}, S_{O V}$ overcritical reflections, $P c P, S c S$ reflections from intra-crustal discontinuities, $P m P$, $S m S$ reflections from the Moho, $P n, P n l, S n$ refractions from the sub-Moho upper mantle, $P^{I}, S^{I}, S^{I I}$ phases from the upper mantle. The reduction velocities are $8.0 \mathrm{~km} / \mathrm{s}$

It is usually difficult to separate the first $\mathrm{S}$-wave arrival (Sg) from the background noise and P-wave coda. In our data it was possible to pick the Sg with almost the same accuracy and similar offsets compared to the Pg (e.g., at SP H $(17,18,22,27,28))$. An apparent velocity $(3.75 \mathrm{~km} / \mathrm{s})$ of the $\mathrm{Sg}$ for five shots of SP H can be traced up to an offset of $100 \mathrm{~km}$. After that, a lower (ca. $3.5 \mathrm{~km} / \mathrm{s}$ ) apparent velocity is observed up to $150 \mathrm{~km}$ offset (Fig. 5). Velocities of $3.6 \mathrm{~km} / \mathrm{s}$ are observed on seismograms of SP P (40 km to the North and $80 \mathrm{~km}$ to the South) (Fig. 8), SP T (60 km to the North and $80 \mathrm{~km}$ to the South) (Fig. 9) and SP R (60 km to both directions). The higher apparent velocity $(3.75 \mathrm{~km} / \mathrm{s})$ is observed at offsets of 150-160 km from SP Q to SW, and up to $220 \mathrm{~km}$ from SP K (Fig. 10). 

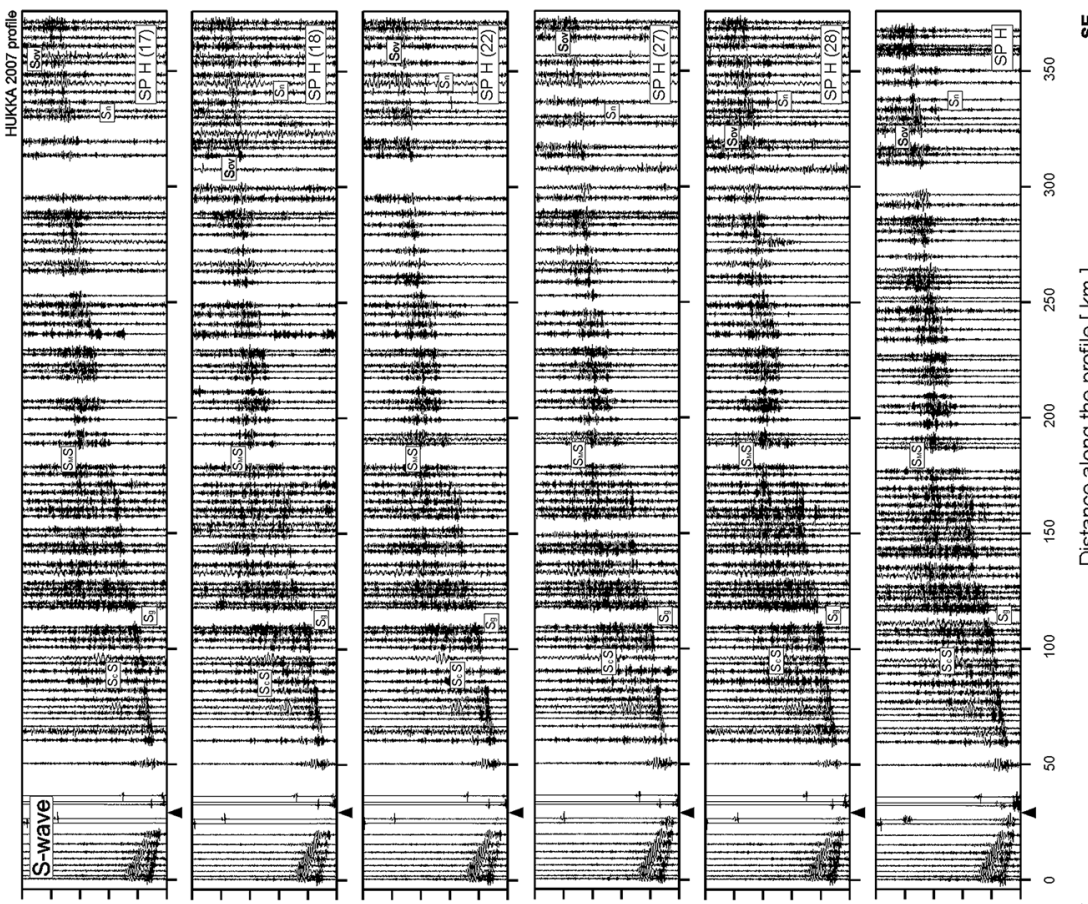

0 , 0

[s] $29 \triangleright / X-\perp$ әщ! $\perp$ рәу
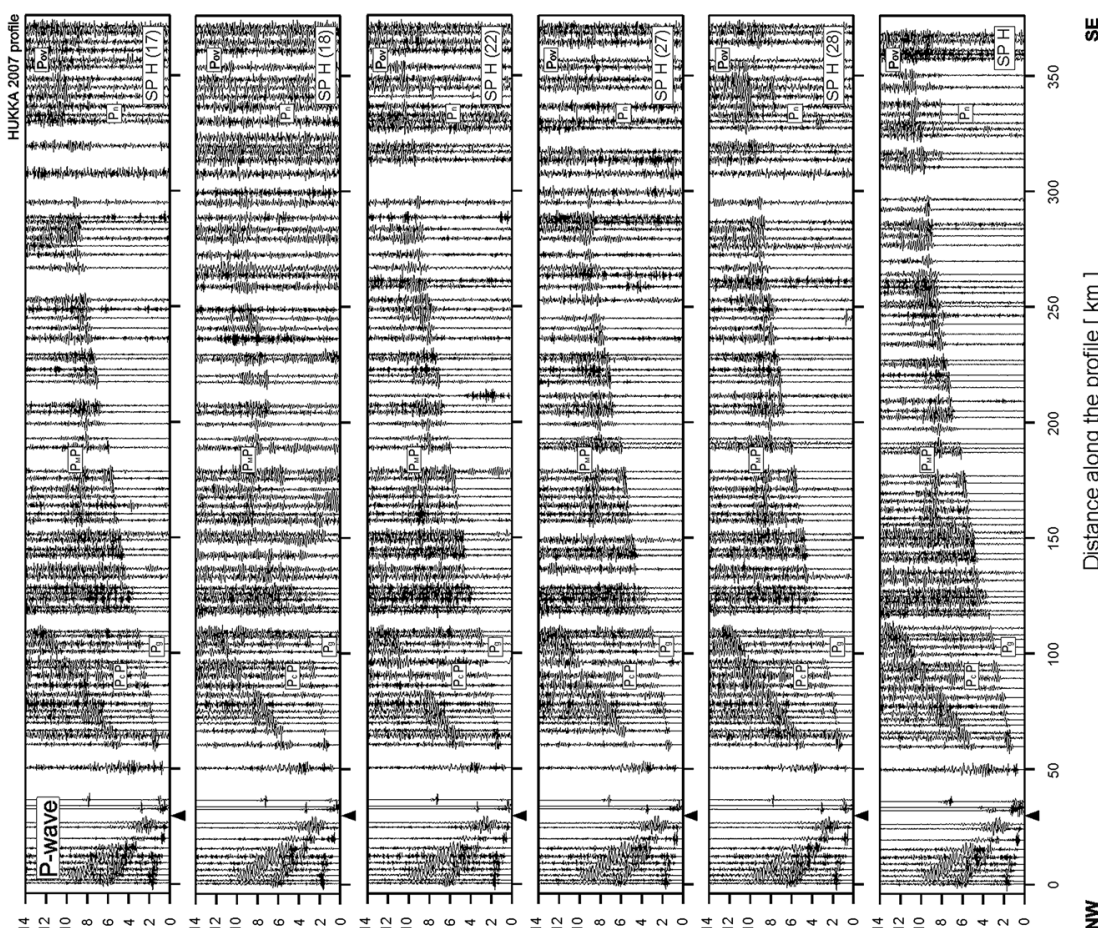

แ

$\bar{\Xi}$ 을

䨌

政

冞

वै

공

응

号䟽

。ํํำ

홍

它

운

竞

ธิ

胥

递

至事

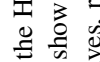

些金落

ने के क

s)

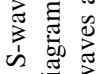

in 0

늘 है

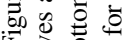

I

i

놓정

웅

을

ปู ज्ञ

$\simeq \infty$

뭉이

远

总: 莺

要

递

चี

ฮี

를

这

要

离

กี้

ถู กิ

$\stackrel{0}{\circ}$

¿ู่

$\exists$

送

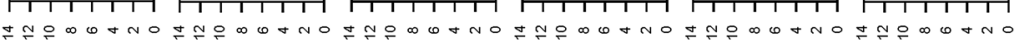

[s] $8 / X-1$ әш! $\perp$ рәу 

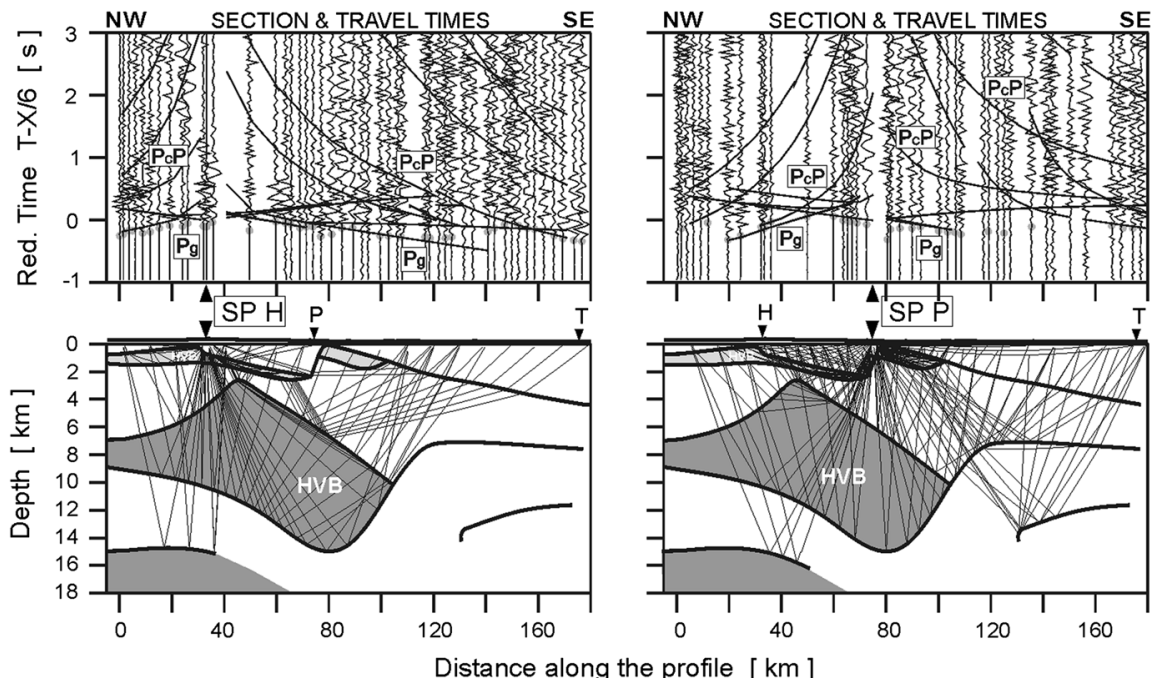

Distance along the profile [ $\mathrm{km}$ ]
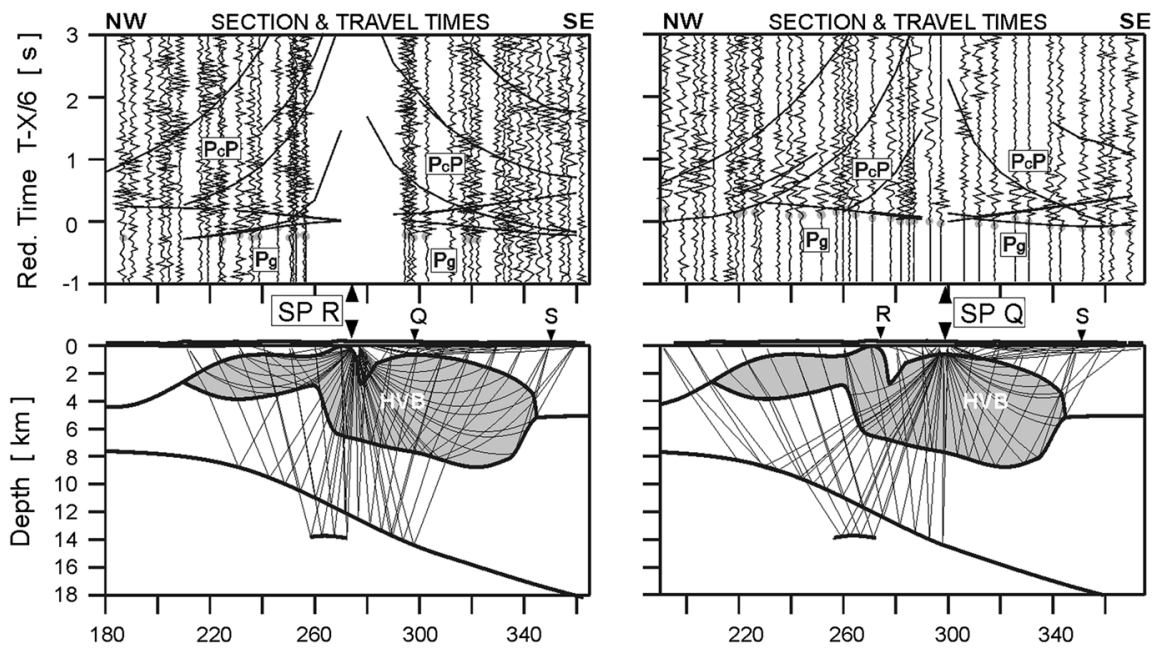

Distance along the profile $[\mathrm{km}]$

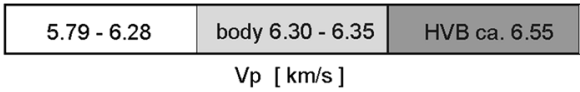

Figure 6

Examples of results derived using the SEIS83 ray-tracing technique for selected parts of the upper crust of the SP H, SP P, SP R and SP Q sections of the HUKKA 2007 profile. Amplitude-normalized seismic record section of $\mathrm{P}$ waves with selected theoretical travel times. The grey dots present correlation of the first arrivals of P-wave and S-wave, PmP and SmS. The data have been filtered using the band-pass filter of $2-14 \mathrm{~Hz}$ and displayed using the reduction velocity of $6.0 \mathrm{~km} / \mathrm{s}$ (upper diagrams). All examples were calculated for the model presented in Fig. 11. $H V B$ high velocity body; other abbreviations are as in Fig. 4

\subsection{Crustal Phases in Later Arrivals, PmP and SmS Phases}

The P-wave and similar S-wave phases reflected within the crust $(\mathrm{PcP}, \mathrm{ScS})$ are generally strong but not always clear. Reflections from the upper crust, at intervals up to $1.5 \mathrm{~s}$ from the first arrivals, can be correlated on many of the record sections (e.g., at SP $\mathrm{H}$ and SP Q) (Figs. 4, 7). In all the five record sections from Hukkavaara hill shots there are several intervals where the amplitudes of mid-crustal reflections are very strong, but clear correlation is not possible. They can be seen from SP H up to the offset 

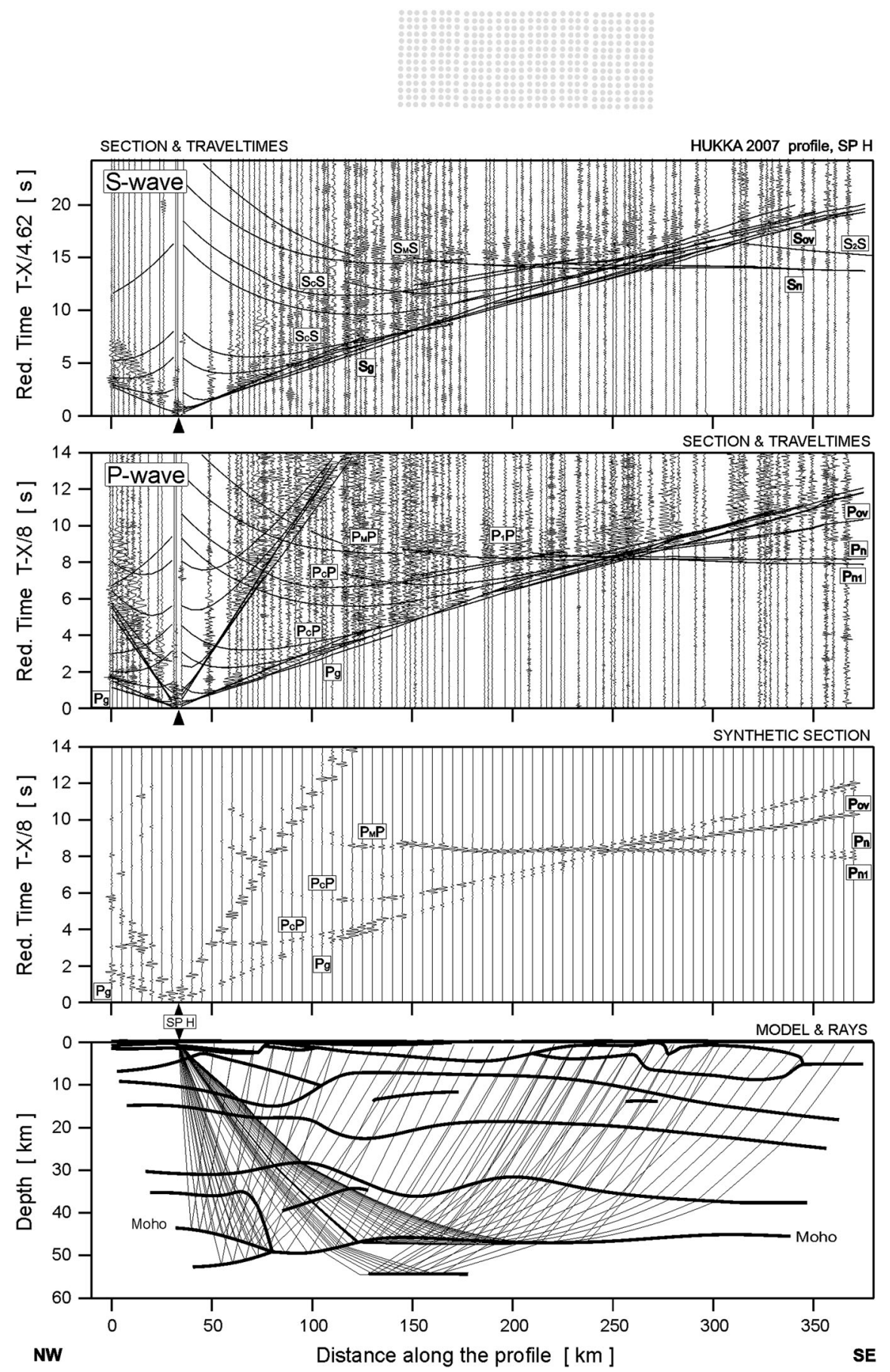

Figure 7

Example of seismic modeling along the HUKKA 2007 profile, SP H; Seismic record sections (amplitude-normalized vertical component) of S-waves and P-waves with theoretical travel times using the SEIS83 ray-tracing technique. For S-waves, we used the band pass filter of 1-6 Hz and reduction velocity of $4.62 \mathrm{~km} / \mathrm{s}$. P-wave data have been filtered using the band-pass filter of 2-14 Hz and displayed using the reduction velocity of $8.0 \mathrm{~km} / \mathrm{s}$ (second diagram). Synthetic seismograms (third) and ray diagram of selected rays (bottom) are shown for P-waves. All examples were calculated for the model presented in Fig. 11. Other abbreviations are as in Fig. 4 

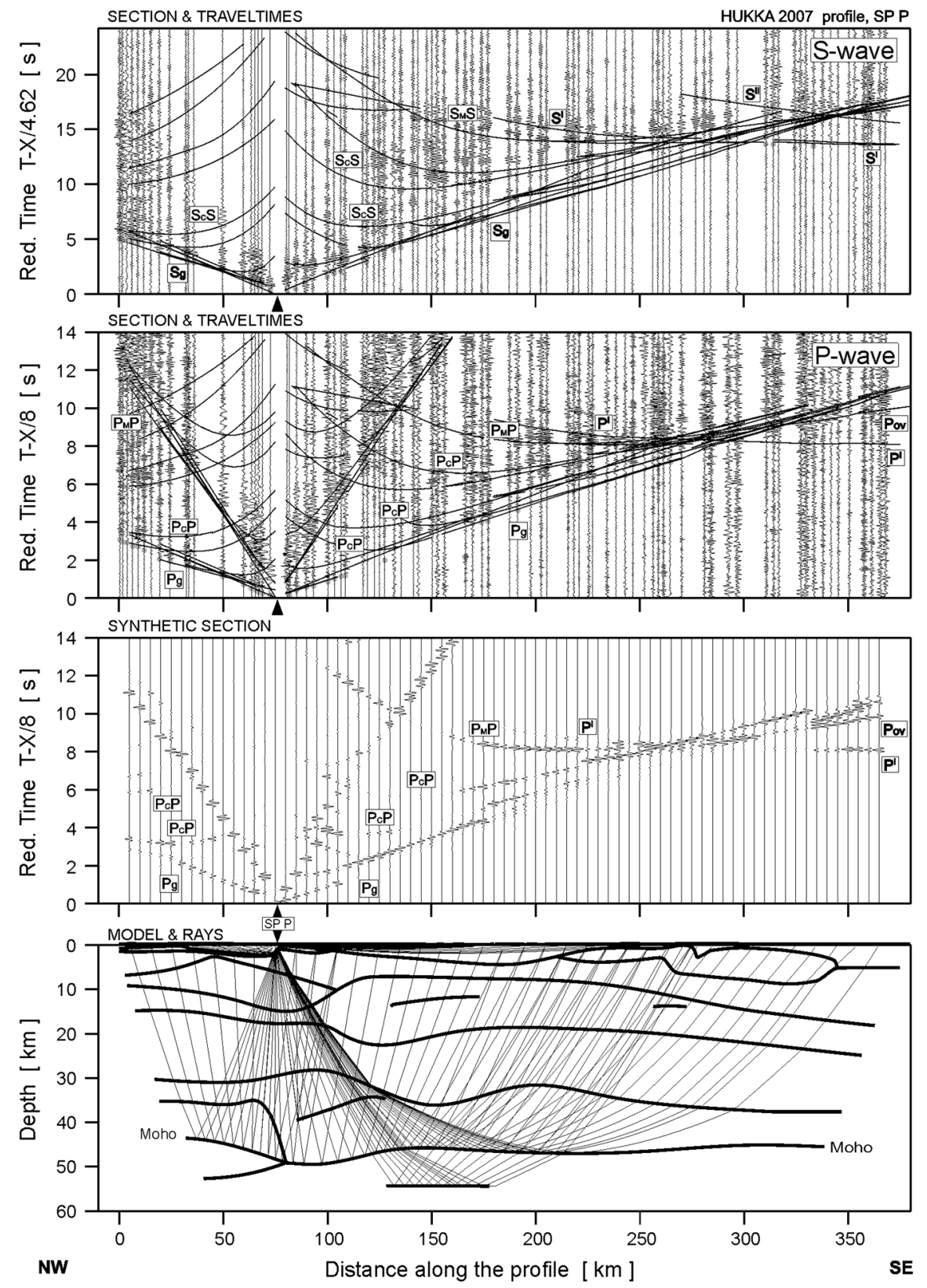

Figure 8

Example of seismic modeling along the HUKKA 2007 profile, SP P; Seismic record sections (amplitude-normalized vertical component) of $\mathrm{S}$-waves and P-waves with theoretical travel times computed using the SEIS83 ray-tracing technique. For S-wave, we used the band-pass filter of $1-6 \mathrm{~Hz}$ and reduction velocity of $4.62 \mathrm{~km} / \mathrm{s}$. P-wave data have been filtered using the band-pass filter of $2-14 \mathrm{~Hz}$ and displayed using the reduction velocity of $8.0 \mathrm{~km} / \mathrm{s}$ (second diagram). Synthetic seismograms (third diagram) and ray diagram of selected rays (bottom diagram) are shown for P-waves. All examples were calculated for the model presented in Fig. 11. Other abbreviations are as in Fig. 4

of $150 \mathrm{~km}$ (Fig. 7) and at all offsets from SP P (Fig. 8), where characteristics of $\mathrm{ScS}$ phases are very similar. Ca. $1 \mathrm{~s}$ after the first arrivals, strong, low frequency pulses are observed at offsets between 105 and $195 \mathrm{~km}$ from SP T (Fig. 9). Well-developed overcritical crustal phases (Pov, Sov) can be correlated by their envelope up to the offset of 220-340 km from SP H (Figs. 5, 7), SP P (Fig. 8) 

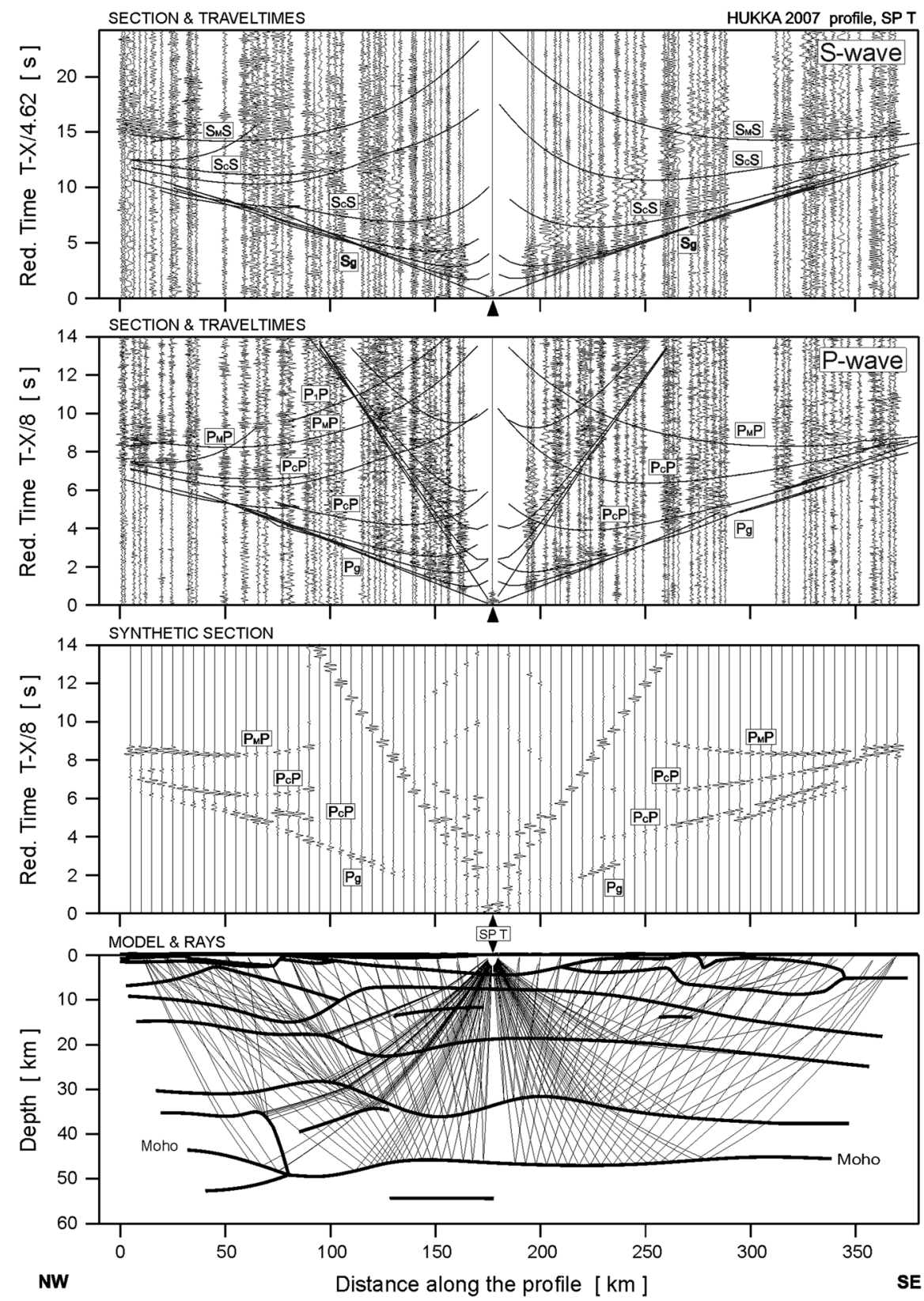

Figure 9

Example of seismic modeling along the HUKKA 2007 profile, SP T; Seismic record sections (amplitude-normalized vertical component) of $\mathrm{S}$-waves and P-waves with theoretical travel times using the SEIS83 ray-tracing technique. For S-waves, we used the band-pass filter of 1-6 Hz and reduction velocity of $4.62 \mathrm{~km} / \mathrm{s}$. P-wave data have been filtered using the band-pass filter of $2-14 \mathrm{~Hz}$ and displayed using the reduction velocity of $8.0 \mathrm{~km} / \mathrm{s}$ (second diagram). Synthetic seismograms (third diagram) and ray diagram of selected rays (bottom diagram) are shown for P-waves. All examples were calculated for the model presented in Fig. 11. Other abbreviations are as in Fig. 4

and SP Q (Fig. 4) or at even larger offsets of 400-450 km from SP K (Fig. 10).

Reflections from the lower crust and the upper mantle can be recognized on the seismograms as pulses with a 1 to $1.5 \mathrm{~s}$ long coda. Particularly strong arrivals of PcP can be observed ca. $0.5 \mathrm{~s}$ before the arrivals of the $\mathrm{P}$-wave reflected from the Moho boundary $(\mathrm{PmP})$ at offsets up to $120 \mathrm{~km}$ on several 

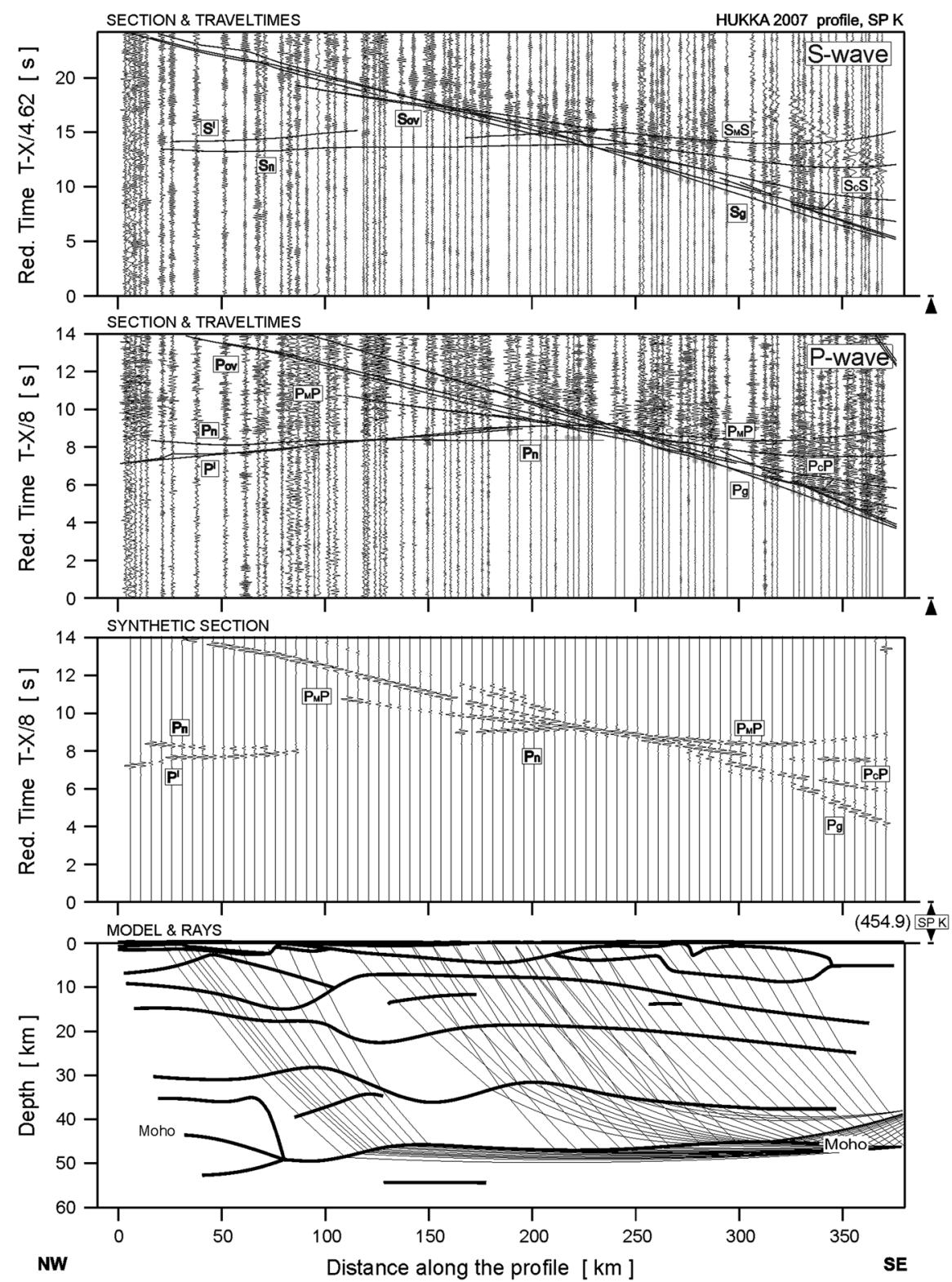

Figure 10

Example of seismic modeling along the HUKKA 2007 profile, SP K; Seismic record sections (amplitude-normalized vertical component) of S-waves and P-waves with theoretical travel times using the SEIS83 ray-tracing technique. For S-waves, we used the band-pass filter of 1-6 Hz and reduction velocity of $4.62 \mathrm{~km} / \mathrm{s}$. P-wave data have been filtered using the band-pass filter of 2-14 Hz and displayed using the reduction velocity of $8.0 \mathrm{~km} / \mathrm{s}$ (second diagram). Synthetic seismograms (third diagram) and ray diagram of selected rays (bottom diagram) are shown for P-waves. All examples were calculated for the models presented in Fig. 11. Other abbreviations are as in Fig. 4

seismic sections (SP H, SP P and SP K) (Figs. 7, 8, 10), with comparable amplitudes. The PmP can be detected as a sharp arrival in some of the record sections, for example, in SP $\mathrm{H}$ at offsets of 90-215 km, SP P at offsets of 80-200 km and SP S at offsets of $130-265 \mathrm{~km}$. In the latter the PmP is very clear, but it should be remembered that this shot was located ca. $65 \mathrm{~km}$ off the line of the profile, and, thus, this reflection could originate from different crustal structure. In other record sections the PmP, if seen, is not so clear and sharp. For example, in seismograms of SP K (Fig. 10) it is visible at offset 
$150-195 \mathrm{~km}$, but in the background of high-amplitude noise.

The recordings of S-waves demonstrate a slightly better quality of reflections from the Moho boundary $(\mathrm{SmS})$ in the record sections, which also have good quality PmP. Similar to PmP, the quality of the SmS is also dependent on the offset. The $\mathrm{SmS}$ arrivals start at shorter offsets in the record sections of shots in the NW part of the profile. For example, the SmS arrivals are visible at offsets of 85-205 km from SP H, while they are seen at offsets of 105-250 km from SP K located in the SE part of the profile.

\subsection{Pn, Sn and Reflected Lower Lithosphere Phases}

The P-wave refracted beneath the Moho boundary $(\mathrm{Pn})$ is weak, and not clearly visible at large offsets in the longest record sections (see Fig. 4). Some pulses with apparent velocity of ca. $8.0 \mathrm{~km} / \mathrm{s}$ are visible in SP H (at offsets of 230-340 km), SP P (at offsets of 260-280 km) and SP K (at offsets of -255 to $280 \mathrm{~km}$ ). One cannot be sure, however, that these pulses are the first arrivals. A similar situation is observed for amplitudes of S-waves refracted beneath the Moho boundary ( $\mathrm{Sn}$ ), but reliable determination of arrivals of $\mathrm{Sn}$ is difficult, if possible at all, because of the higher level of background noise (see Fig. 4a, c). Apparent velocities of observed arrivals are $4.75 \mathrm{~km} / \mathrm{s}$ or even more (SP H, and SP K) (see e.g., Figs. 7, 10).

Strong reflections with comparable amplitudes are recorded just after $\mathrm{PmP}(0.6 \mathrm{~s})$ and $\mathrm{SmS}$ (0.9 s after) on some record sections (see SP H, SP S and SP Q). Also, strong reflections from the upper mantle $\left(\mathrm{P}^{\mathrm{I}}, \mathrm{S}^{\mathrm{I}}\right.$ and $\left.\mathrm{S}^{\mathrm{II}}\right)$ are seen on the record sections of SP H and SP K (see e.g., Figs. 4, 5).

\section{Velocity Model for the HUKKA 2007 Profile}

The velocity model (Fig. 11) was obtained using the ray-tracing method. Arrivals were picked and phases correlated from the record sections using the ZPLOT program by ZELT (1994) modified by ŚRODA (1999). Reciprocal travel times between sections from different shot points were used to ensure the

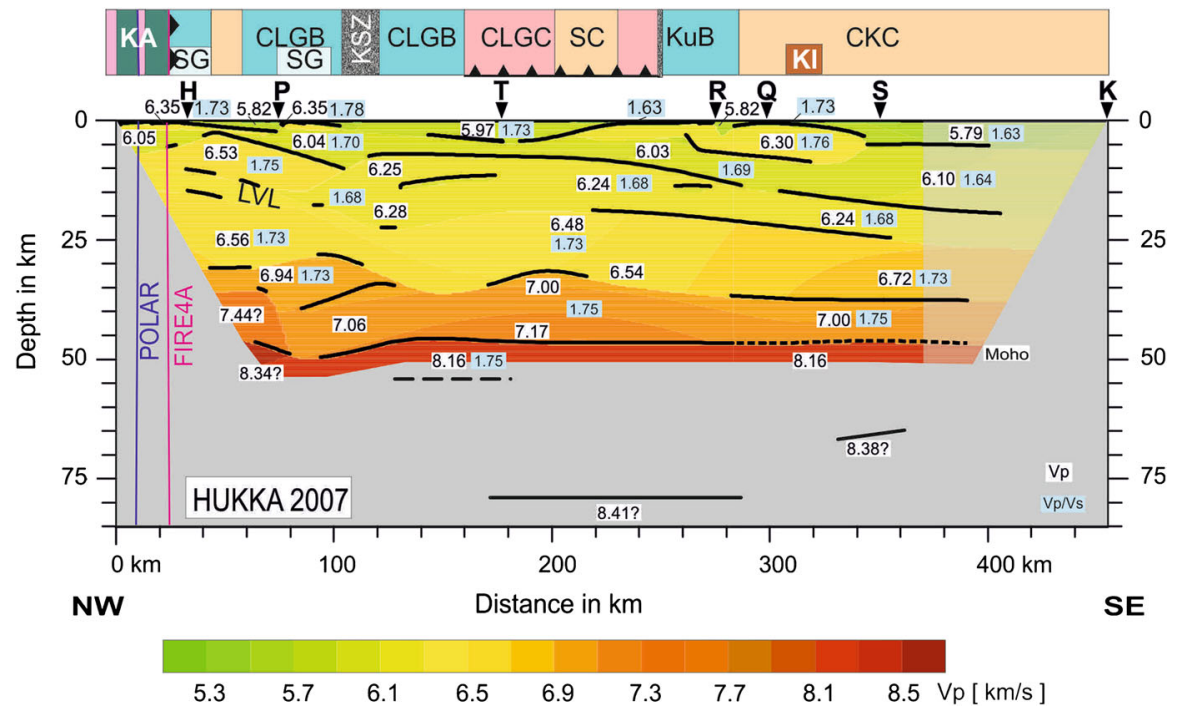

Figure 11

P-wave velocity and Vp/Vs-ratio crustal model and lithological strip along the HUKKA 2007 profile. Thick, black lines represent major velocity discontinuities (interfaces). Velocity values in $\mathrm{km} / \mathrm{s}$ are shown in white boxes. The values in light blue rectangles show the values of the Vp/Vs ratio. LVL locates a low velocity layer. Arrows show positions of shot points. Color code for the lithology is the same as in Fig. 2. The model displays a partly buried paleorift. High velocity bodies are associated with mafic lithologies and lower velocities with sedimentary and granitic material. Abbreviations CKC Central Karelian craton, CLGB Central Lapland greenstone belt, CLGC Central Lapland Granitoid complex, $K A$ Kittilä allochthon, $K i$ Koillismaa layered intrusion complex, $K S Z$ Kittilä Shear Zone, $K u B$ Kuusamo belt, $S C$ Suomu complex, $S G$ Savukoski Group 
correctness of the correlations. The ray-tracing and the theoretical travel times (see Figs. 6, 7, 8, 9, 10) were computed with the SEIS83 program package (ČERVENÝ and PŠENČíK 1983). The trial and error method was used to fit the theoretical travel times to observed travel times. The model was gradually changed between repeated computations of the theoretical travel times. The iteration was continued until the difference between observed and theoretical travel times was mostly $<0.1 \mathrm{~s}$. Model velocities were fitted to observed travel times from top to bottom. The gray dots on Figs. 6, 7, 8, 9, 10 present correlation of the first arrivals of P-waves and S-waves. Synthetic seismograms (see Figs. 7, 8, 9, 10) were computed with the SEIS 83 program package for dynamic modeling. In dynamic modelling the synthetic amplitudes were fitted to observed amplitudes by visual inspection. This helped to define the velocity contrasts between the layers. The final model consists of a three layer model of the crust with crustal reflectors, the Moho boundary, Pn velocity and some reflectors in the upper mantle.

\subsection{P-Wave Velocity Model}

In the 4-20 km thick upper crust, the P-wave velocity varies generally between 5.8 and $6.1 \mathrm{~km} / \mathrm{s}$. In three high velocity zones (HVZ) the velocity is about $6.3 \mathrm{~km} / \mathrm{s}$. A $4-7 \mathrm{~km}$ thick HVZ starts at $210 \mathrm{~km}$ and ends at $350 \mathrm{~km}$ profile distance. The HVZs and some reflectors separate the upper crust into two layers. The velocities in the upper layer are between 5.78 and $6.0 \mathrm{~km} / \mathrm{s}$. In the lower layer the velocities are between 6.0 and $6.1 \mathrm{~km} / \mathrm{s}$. The bottom of the upper crust is at a depth of $20 \mathrm{~km}$ near the southern end of the profile. Towards the north the bottom of the upper crust rises reaching $9 \mathrm{~km}$ at distances $120-140 \mathrm{~km}$. At $110 \mathrm{~km}$ distance there is an abrupt drop of $3 \mathrm{~km}$ towards the north in the thickness of the upper crust. From 110 to $45 \mathrm{~km}$ the thickness of the upper crust decreases to only about $4 \mathrm{~km}$ and then increases to about $7 \mathrm{~km}$ at the start of the profile.

In the middle crust the P-wave velocity varies between 6.2 and $6.75 \mathrm{~km} / \mathrm{s}$. In the northern part of the profile the velocity of the middle crust is relatively high, $6.5-6.6 \mathrm{~km} / \mathrm{s}$, excluding a $4 \mathrm{~km}$ thick low velocity layer (LVL) in the depth interval of 10-18 km dipping to the south and ending at a distance of $110 \mathrm{~km}$. The velocity in the LVL is $6.30-6.35 \mathrm{~km} / \mathrm{s}$. From $110 \mathrm{~km}$ to the southern end of the profile, the velocities are rather stable, $6.25-6.30 \mathrm{~km} / \mathrm{s}$ in the upper part of the middle crust. In the lower part of the middle crust, the velocities are between 6.5 and $6.6 \mathrm{~km} / \mathrm{s}$ at distances of $0-110 \mathrm{~km}$ and between 6.45 and $6.5 \mathrm{~km} / \mathrm{s}$ at distances of $110-210 \mathrm{~km}$. From a distance of $210 \mathrm{~km}$ towards the south these velocities gradually increase reaching $6.7 \mathrm{~km} / \mathrm{s}$ at a distance of $360 \mathrm{~km}$. In the southern part of the profile a strong reflector at a depth of 19 at a distance of $220 \mathrm{~km}$ deepening to 25 at a distance of $355 \mathrm{~km}$ separates the upper and lower parts of the middle crust. The velocity contrast at the reflector is $0.20 \mathrm{~km} / \mathrm{s}$ at a distance of $220 \mathrm{~km}$ and $0.45 \mathrm{~km} / \mathrm{s}$ at a distance of $400 \mathrm{~km}$. The boundary between the middle crust and the lower crust is at a depth of $38 \mathrm{~km}$ in the southern part of the profile shallowing to 32 at a distance of $200 \mathrm{~km}$. In the northern part of the profile the boundary between the middle crust and the lower crust undulates in the depth range $28-36 \mathrm{~km}$. In the lower crust the P-wave velocity varies between 6.9 and $7.2 \mathrm{~km} / \mathrm{s}$ with the exception of velocities of $7.4-7.5 \mathrm{~km} / \mathrm{s}$ in a high velocity body above the Moho at the northern end of the profile.

The Moho depth is $46 \mathrm{~km}$ beneath most of the model. At distances from 60 to $120 \mathrm{~km}$ there is a depression reaching a depth of $50 \mathrm{~km}$ at a distance of $92 \mathrm{~km}$. The Pn velocity below the Moho is $8.15 \mathrm{~km} / \mathrm{s}$ in the central part of the model. At the north-western end of the model the Pn velocity is probably higher, about $8.35 \mathrm{~km} / \mathrm{s}$.

\subsection{S-Wave Velocity Model and Vp/Vs Ratio}

The S-wave velocity model was compiled using the same layer structure as in the P-wave model. Only the velocities were changed in the iteration process. The $\mathrm{Vp} / \mathrm{Vs}$ velocity ratios are presented in Fig. 11. In the upper crust the $\mathrm{Vp} / \mathrm{Vs}$ ratio varies between 1.63 and 1.78. The largest lateral variation is found near the surface. The highest values are found in HVZs. At the bottom of the upper crust the variation is smoother. There the $\mathrm{Vp} / \mathrm{Vs}$ values increase from 
1.64 in the southern part of the profile to 1.70 in the northern part of the profile. In the middle crust the $\mathrm{Vp} / \mathrm{Vs}$ ratio varies between 1.68 and 1.75 . The highest values are seen in the first $110 \mathrm{~km}$ of the profile above the LVL. Otherwise the variation is rather smooth. In the uppermost part of the middle crust south of $110 \mathrm{~km}$ distance, the $\mathrm{Vp} / \mathrm{Vs}$ ratio is almost constant at 1.68. In the lower part of the middle crust, the $\mathrm{Vp} / \mathrm{Vs}$ ratio is 1.73 along the whole profile. In the lower crust, the $\mathrm{Vp} / \mathrm{Vs}$ ratio is 1.75 except for the first $120 \mathrm{~km}$ of the model where slightly lower values (1.73) are observed. Below the Moho, the Vp/Vs ratio is 1.75 .

\subsection{Resolution Analysis for the Models Obtained by the Ray-Tracing}

The main sources of inaccuracy in the results are errors in picking the observed travel-times, misfits in fitting the observed and theoretical travel times, the ray coverage and errors in interpretation of the correlated observed travel times. Factors affecting these causes of error are the signal-to-noise ratio (SNR) and the spatial profile lay-out of the profile. In the HUKKA 2007 profile data set day-time shooting and delayed shooting in quarries deteriorates SNR but the small amount of seismic noise originating from human activity in this sparsely inhabited study area improves SNR.

JANIK et al. (2002) found that in a study made with the same methods, the uncertainties of velocity determinations were lower than $0.2 \mathrm{~km} / \mathrm{s}$ and that uncertainty in the depths of intracrustal and Moho reflectors were $<2 \mathrm{~km}$. The crustal structure in their study is more complicated than in the model of the HUKKA 2007 profile. On the other hand, the number of shot points is smaller in our study and, thus, the ray coverage is not as good and some of the shot points reside offline, which brings more uncertainty to the results. In general their accuracy estimation is applicable to the current study.

\subsection{Interpretation of the Model}

The HUKKA 2007 profile runs NW-SE and transects five terranes with different structural grains: the KA, the CLGB, the eastern part of the CLGC, the
Kuusamo schist belt $(\mathrm{KuB})$ and the Central Karelian Craton (CKC) (Fig. 3). At the northeastern end, the profile runs parallel to the thrust direction of the KA. It enters obliquely into the basin structure of the CLGB and within the CLGB it crosses at a very oblique angle the KSZ. It then enters the CLGC where it runs perpendicular to the thrust direction of the CLGC and the SC. Further south the profile transects obliquely the basin structure of the KuB. Within the $\mathrm{CKC}$, the shot points are considerably offline and, thus, structural control at the surface cannot be used to constrain the interpretation.

Generally, we can distinguish three major layers in the crust beneath the HUKKA 2007 profile. The thickness of the upper crust varies from $15 \mathrm{~km}$ in the southern part of the profile to $5 \mathrm{~km}$ in its northern part. The upper crust is heterogeneous and major geological units can be distinguished as variations in $\mathrm{Vp}$ and $\mathrm{Vp} / \mathrm{Vs}$ ratio. The middle crust extends down to a depth of $30 \mathrm{~km}$ in the northern part of the profile and to about $35 \mathrm{~km}$ in the southern part of the profile. The lower crust is thin and rather homogeneous, with velocities and $\mathrm{Vp} / \mathrm{Vs}$ ratios typical for mafic granulites (KERN et al. 1993, JANIK et al. 2007, 2009).

The HUKKA 2007 profile images a layered crust with heterogeneous upper crust. The crustal structure of the northern half of the profile is symmetric in that it displays low angle reflections dipping SE in the northern part and NW in the southern part and subhorizontal in the middle. The northern change in the apparent dip direction takes place around the KSZ, associated with low velocities and low $\mathrm{Vp} / \mathrm{Vs}$ ratios. The velocity variations are similarly symmetric showing high velocities in the northern and southern parts and lower values in the middle. The upper crust shows high velocity-high $\mathrm{Vp} / \mathrm{Vs}$ ratio bodies $(\mathrm{Vp}>6.30 \mathrm{~km} / \mathrm{s}, 1.76)$ that seem to be associated with either mafic rocks of the Koillismaa layered intrusion complex, the Kittilä oceanic plateau or the Savukoski Group of the Central Lapland Greenstone belt (KA, SG, KI). The high velocity bodies are embedded in the low velocity, low $\mathrm{Vp} / \mathrm{Vs}$ ratio background ( $\mathrm{Vp}<6.25 \mathrm{~km} / \mathrm{s}, 1.63-1.70)$ consisting of granitoids and clastic metasedimentary rocks. Note that the thickest parts of the low velocity upper crustal material are associated with either thick sections of metasediment-rich rift sequences (CLGB) 
or granitoid and gneiss nappes (CLGC, SC) or granite-migmatite-gneisses units (CKC). The lower crust hosts a 10-20 km thick high velocity layer with high $\mathrm{Vp} / \mathrm{Vs}$ ratios $(\mathrm{Vp}>7 \mathrm{~km} / \mathrm{s}, \quad \mathrm{Vp} / \mathrm{Vs}>1.75)$ indicating mafic compositions.

\section{Discussion}

The velocity distribution of the HUKKA 2007 profile is similar to other profiles crossing Lapland and the Fennoscandian Shield.

The CLGC (Fig. 3) is a relatively large unit stretching across the northern part of Finland and transected also by the HUKKA 2007 profile. It has been formed by Paleoproterozoic intrusions 2.1$1.7 \mathrm{Ga}$ years ago. The area is not well exposed, but granites and pegmatites are major rock types in outcrops (KoRsman et al. 1997; Lahtinen et al. 2005; Patison et al. 2006). Recently, Silvennoinen et al. (2010) showed that one of the most pronounced features in the western part of the CLGC is the high velocity (up to $6.3 \mathrm{~km} / \mathrm{s}$ ), high density, reflective body inside the Central Lapland Granitoid Complex. The body is not exposed at the surface, and it is limited from the top by a boundary at the depth of $2 \mathrm{~km}$. This feature is not observed in the eastern part of the CLGC crossed by the HUKKA 2007 profile, where generally lower crustal velocities and $\mathrm{Vp} / \mathrm{Vs}$ ratios are seen down to the depth of $30 \mathrm{~km}$ (Fig. 11). Generally, seismic velocities in the upper and middle crust are similar to those beneath the Central Finland Granitoid complex in southern Finland (c.f. JANIK et al. 2007). Also the high upper crustal velocities of the Kittilä and Savukoski groups are in good agreement with those detected along the POLAR profile by JANIK et al. (2009), who detected high values of Vp (up to $6.5 \mathrm{~km} / \mathrm{s}$ ) in the uppermost crust.

Another interesting features of the velocity model in Fig. 11 are low values of the Vp/Vs ratio in the upper and middle crust beneath Central Karelian craton in the southeastern part of the profile. The low values could be explained by amphibole-rich and biotite and muscovite poor tonalites, (Fig. 12, SILVENNOINEN and KozlovsKaya 2006) typically found in $\mathrm{CKC}$ and in other Archean gneiss terranes.

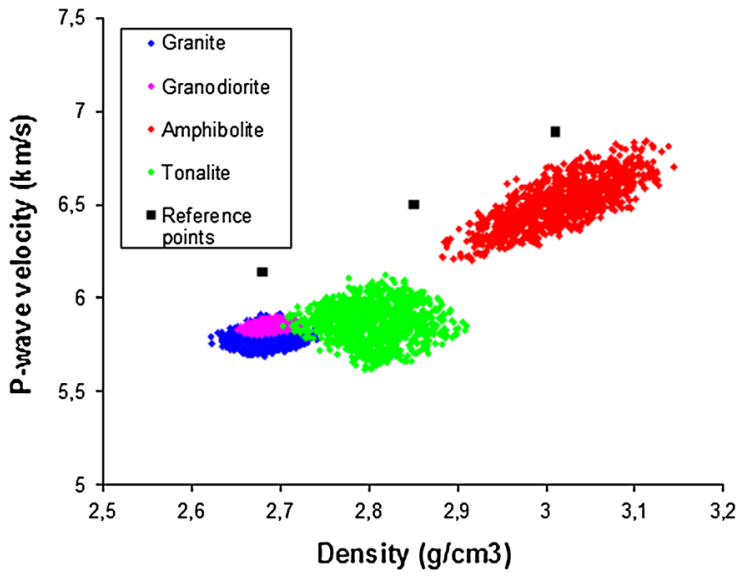

Figure 12

Density-seismic velocity diagrams for major rock types of Kuhmo block calculated with the Monte Carlo method from modal mineralogy using modal mineralogy analyzed by Lindberg and Kukkonen (in ANTTILA et al. 1990) (Adopted from SiLvenNoinen and Kozlovskaya 2006). Reference velocity-density curve from Soвolev and BАвеYко (1994) is shown by black dots. As can be seen, the rocks have lower values of $\mathrm{Vp}$ than the reference curve, which explains lower values of the $\mathrm{Vp} / \mathrm{Vs}$ ratio

The most complex structure in the crust is seen beneath the Kuusamo schist belt and the Central Karelian craton. Recently, the crust in this area has been investigated using $\mathrm{P}$-wave receiver functions (PRF) estimated from the recordings of teleseismic events by the POLENET/LAPNET broadband array (Silvennoinen et al. 2012, submitted). The study revealed a very complex crustal structure and a very deep (about $60 \mathrm{~km}$ ) Moho beneath these units. This Moho depression appears to be the limit of the generally thin (about $44 \mathrm{~km}$ ) crust of the Karelian craton from the north, and a continuation of the Moho depression detected in a previous study by KozLovsKAYA et al. (2008). A good compilation of Moho depths from previous studies in this area can be found in GRAD et al. (2009). New features concerning Moho depths found in this study are the slightly deeper $(2 \mathrm{~km})$ Moho in the central part of the model and the clearly deeper $(4 \mathrm{~km})$ depression at the model distance of $90 \mathrm{~km}$. The tomographic velocity model of HYvöNEn et al. (2007) covers the area of the HUKKA 2007 line for about $100 \mathrm{~km}$ south of SP Q. The P-wave velocities in our model are about $0.2 \mathrm{~km} / \mathrm{s}$ higher at depths greater than $15 \mathrm{~km}$. From 0 to $15 \mathrm{~km}$ depths the average velocities are more similar. 
Similarly the average $\mathrm{Vp} / \mathrm{Vs}$ values are $0.01-0.03$ higher in our model compared to HyvöNEN et al. (2007). The largest differences occur from 15 to $25 \mathrm{~km}$ depths. UsKi et al. (2012) compiled a P-wave model which included the area of the HUKKA 2007 model. The model of UsKi et al. (2012) was computed using permanent stations and a very sparse data set. Thus, the model lacks in detail. The main differences between the models are an approximately $0.2 \mathrm{~km} / \mathrm{s}$ faster middle crust and an approximately $3 \mathrm{~km}$ deeper Moho boundary in the HUKKA 2007 model.

The HUKKA 2007 profile reveals that the crustal structure of Central Lapland is dominated by an old continental rift structure. The geometry of the central part of the Lapland rift (Fig. 11, distances 0-350 km) with its inward dipping structures and high velocity lower crust resembles that of the East African and Midcontinent rifts (BeHRENDT et al. 1988, Keranen et al. 2004). The rift shoulders are characterized by higher than average velocities $(6.5 \mathrm{~km} / \mathrm{s})$ associated with extended Neoarchean crust intruded by Paleoproterozoic mafic magmatism, whereas the center of the rift is characterized by lower velocities and $\mathrm{Pa}-$ leoproterozoic rift-related volcano-sedimentary rocks (CLGB) and granitoid rocks (CLGC).

The CLGB comprises volcano-sedimentary rocks found in a NE-SW elongated basin delineated by shear zones. Similar rock associations are found on both sides of the KSZ. On the southern side, the rift related formations are covered by the allochthonous CLGC (PATison et al. 2006). On the HUKKA 2007 profile, the direction of the dip changes from dominantly SE wards dipping to NW dipping where the profile crosses the KSZ. We suggest here that the KSZ is originally a transfer fault that separated two basement units (Southern and Central Lapland), rifting at a different velocity and having opposite dip directions (conjugate pair) (Fig. 3; see LisTer et al. 1986). This scenario indicates that the Lapland rift was formed by the northwesterly movement of Central and Southern Lapland away from the Western and Central Karelia Craton.

The northwesterly direction of extension is also supported by the opening of the Peräpohja and Kuusamo rift basins and the intrusion of layered mafic intrusions on the rift shoulders (Fig. 3). A swarm of NW-SE directed fracture zones (e.g., MSZ) cutting the CFGC could also represent other transfer faults within the southern Lapland block. The continental rift may have developed into a passive margin in the $\mathrm{NE}$, from where the KA with an ophiolitic rim was later obducted onto the CLGB during the LaplandSavo orogeny. The orogeny may also have caused the slight thickening observed at the NE end of the profile.

Several authors (AMElin et al. 1995; HeAman 1997; Hanski and Huhma 2005; Melezhik 2006; LAHTINEN et al. 2008) have suggested that the layered intrusions were triggered by the arrival of a plume head beneath Lapland. We suggest that the arrival of the plume not only initiated a continental spreading centre or triple junction (Fig. 13; WKC, CKC + BP and CL (=CLGC + CLGB)) but also resulted in large scale mafic underplating of the crust. We interpret the lowermost high velocity $(\mathrm{Vp}>7 \mathrm{~km} / \mathrm{s})$, high $\mathrm{vp} / \mathrm{vs}-$ ratio $(>1.73)$ to be composed of mafic material. Similarly to the Midcontinent rift structure (BEHRENDT et al. 1988), we interpret the undulating mafic, lower crustal layer to image an underplated part of a failed rift. The high velocity layer is observed in much of the Karelian craton riddled with mafic dykes (KoRJA et al. 1993). It is, however, missing below Lapland

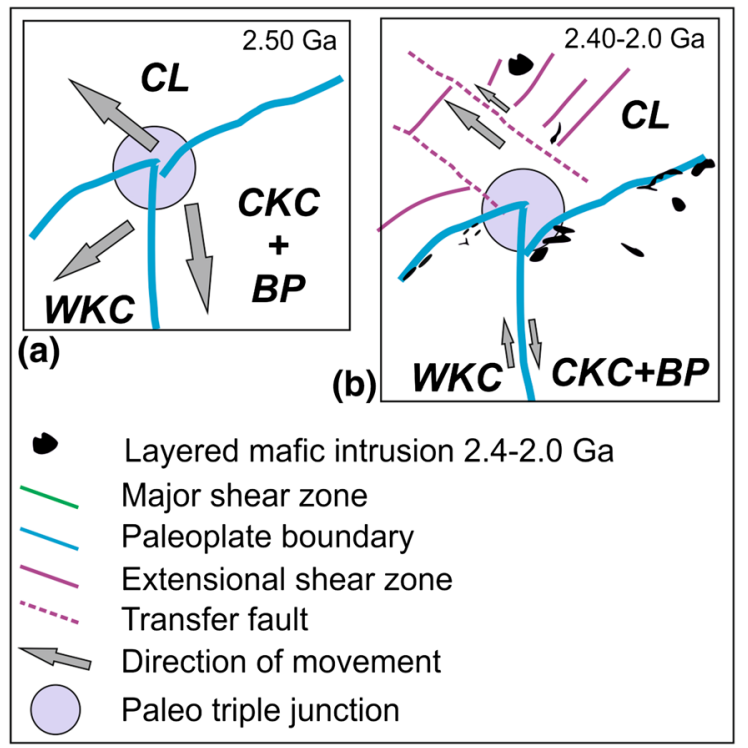

Figure 13

The evolution of the Lapland triple junction. a Initiation of triple junction above a mantle plume. b Development of the Lapland rift in a plume environment. Abbreviations BP Belomorian Province, $C K C$ Central Karelian craton, $C L$ Central Lapland, WKC Western Karelian craton 
granulite belt (LGB; JANIK et al. 2009)—an alleged backarc basin between two rifting margins (DALY et al. 2006, LAHTINEN et al. 2005). The interpretation is also corroborated by the mantle origin of the abundant mafic magmatism observed as mafic layered intrusions and dykes (HANSKI and HuHMa 2005; MeLEZHIK 2006).

At around $2.5 \mathrm{Ga}$ ago the Archean supercontinent was placed above a mantle plume (HANSKI and HuHMA 2005; MelezhiK. 2006). In the Karelia-Belomorian orogenic terrane it results in doming, initiation of intracratonic volcano-sedimentary basins ( $\mathrm{PB}, \mathrm{KuB}$, $\mathrm{KaB}, \mathrm{CLGB}$ ) and the intrusion of mafic layered intrusions and dykes. Layered mafic intrusions (FIRE4) and thick sills (FIRE1) are found along the contact between the basement and large basins (KuB, PB, KaB; Fig. 3). Seismic surveys (FIRE1, FIRE4) have revealed that the intrusions have intruded along shear zones dipping towards the sedimentary basins (Korja et al. 2006, Patison et al. 2006). The contact zones are here interpreted to be located on the rift shoulders and to mark the zone of initial plate rupture i.e., preliminary plate boundaries (Fig. 3). The rupture zones form three rift arms that define a new triple junction (here named the Lapland triple junction) and new plates (WKC, CKC + BP and CL) spreading away to the SW, S and NE from the junction (Fig. 13). The dispersal of the supercontinent has begun.

The dispersal resulted in several rift zones with varying success in developing into continental rifts, failed rifts or ocean basins on the Fennoscandian Shield (LAHTinen et al. 2008). From the Lapland triple junction three rift arms developed: the NE-SW trending Peräpohja aulacogen (PB; HuHma et al. 1990), the NS trending Kainuu rift that developed into an intracratonic ocean basin by $1.97 \mathrm{Ga}$ (Jormua ophiolite, Peltonen 2005; Lahtinen et al. 2005) and the Lapland rift (HANSKi and Hunma 2005). Even the third arm may have developed into an oceanic basin in its northwestern parts from where ophiolitic rocks bordering oceanic plateau rocks have been documented (Nuttio ophiolites surrounding KA, HANSKI and HuHMA 2005).

The spreading direction of the Lapland rift is revealed by the major NW-SE trending strike-slip shear zones and minor orthogonal shear zones and tectonic contacts of the Archean-Paleoproterozoic basin contacts within the CLGB (Figs. 3, 13b). The
KSZ is a well-known crustal scale dextral shear zone that runs NNW-SSE. On the FIRE4 deep seismic reflection line, the shear zone could be followed at least to the middle crust (PATISON et al. 2006). Based on the change in large scale reflection patterns across the boundary, PAtison et al. (2006) and later KorJA and HEIKKINEN (2008) suggested that it is a transform fault that was acting during the Svecofennian orogen. Although there are major disruptions in the lithological formations across the shear zone, the tectonic environment does not change radically and rift related formations are found on the both sides of the zone. It is thus possible that the KZS originated as a large scale transfer fault within the Lapland rift. If it is indeed a rift related transfer fault, it should be accompanied by a set of parallel faults and shear zones. Such faults could be, e.g., the Meltaus shear zone (MSZ) and Ailanka fault (AF). The Ailanka fault and its parallel counterparts in Russian Karelia (CKC) have previously been associated with rift related transcurrent faults by TURCHENKo (1992) and AIro (1999). Seismic reflection data from the FIRE4 profile suggest that the Meltaus shear zone is a major crustal scale boundary flooring a deeply buried graben to the SW. The orthogonal shear zones and tectonic contacts are images of a shallow dipping to sub-horizontal structures in the upper crust along the FIRE4 profile that unfortunately traverses along the dip or obliquely to the dip. In summary, the Lapland rift is characterized by NW-SE trending transfer faults and NE-SW directed low angle shears suggesting spreading in the NW-SE direction.

The HUKKA 2007 profile transects the rift in NW-SE direction. The strike direction of the HUKKA profile has a cross-dip of $20^{\circ}$ with the spreading direction and, thus, it images a slightly oblique section of the rift (Fig. 14). The dip directions of the crustal structures changes from SE dipping to NW dipping across the KSZ and back to SE dipping below the $\mathrm{KuB}$. Such a change could indicate a change from lower plate to upper plate geometries in a simple shear environment (Fig. 3; LISTER et al. 1986). A simple shear deformation environment is also warranted by the crustal scale low angle detachment (Kaukonen Shear Zone) identified from the FIRE4 reflection data set (PAtison et al. 2006). The simple shear model predicts that oceanic crust could form in the extended 


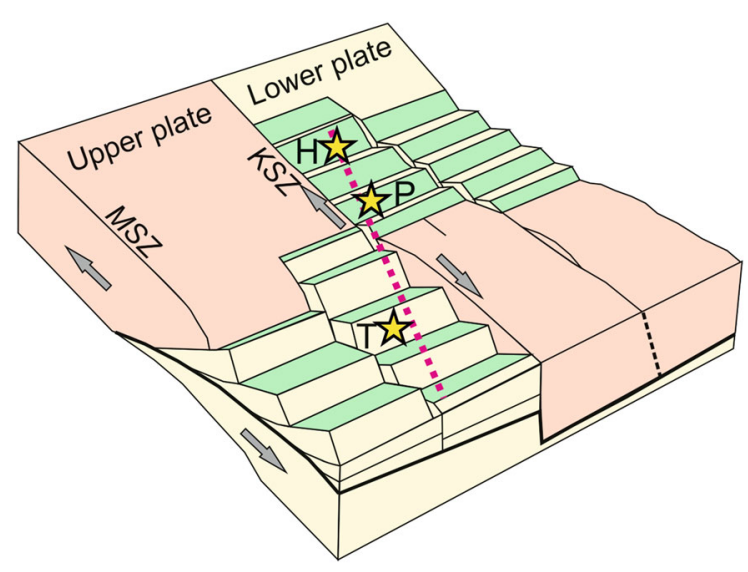

Figure 14

Tectonic block model of the Central Lapland rift at 2.4-2.0 Ga adopted after LISTER et al. (1986). This figure illustrates a tectonic spreading environment at the beginning of continental rifting (Lister et al. 1986). The northwestern part of the HUKKA 2007 profile (dashed line and SP H, P and T) cross-cuts the center of the rift nearly perpendicular to the strike. The profile is at $20^{\circ}$ crossangles with the spreading direction and shows an oblique section of the rift. Major strike slip faults KSZ and MSZ indicate the spreading direction and the location of major structural changes. Abbreviations are as in Fig. 2

edge of the lower plate. This suggests that the NW part of the rift, where ophiolitic rocks have formed, has acted as the lower plate during the advanced stages of rifting. In the upper plate environment more sedimentary filled half grabens are forming and mafic magma may underplate the area. South of the KSZ an abundance of clastic continental derived sediments intruded by mantle derived mafic sills is found (Sodankylä Group; HANSKi and HuHMA 2005).

The present crustal structure of the paleorift was finalized during the Svecofennian orogeny. The crustal depression was filled by materials from the nearby areas and by thin-skinned stacking of paraautochtonous and allochthonous materials of the thinned crust (PB, KuB, CLGC; , Fig. 3) as suggested by FIRE4 (PATISON et al. 2006). Thermal maturation of the thickened crust led to partial melting and emplacement of the migmatites and granites with inherited Archean zircons in the CLGC.

\section{Conclusions}

The HUKKA 2007 profile images a layered crust with heterogeneous upper crust. The thickness of the upper crust varies from $15 \mathrm{~km}$ in the south to $5 \mathrm{~km}$ in the northern part. The upper crust is heterogeneous and major geological units can be distinguished by variations in $\mathrm{Vp}$ and $\mathrm{Vp} / \mathrm{Vs}$ ratio values. The upper crustal structure displays low angle reflections dipping SE in the northern part, NW dipping reflections in the central part and sub-horizontal reflections in between. In the northwest, the change in the apparent dip direction takes place around the KSZ associated with low velocities and low $\mathrm{Vp} / \mathrm{Vs}$ ratios. High velocities are found in the northern part of the profile and in the Kuusamo area whereas lower values are found in the central parts and at the southeastern end. In the upper crust, high velocity $(\mathrm{Vp}>6.30 \mathrm{~km} / \mathrm{s}$ ) and high $\mathrm{Vp} / \mathrm{Vs}$ ratio (1.76) bodies are embedded in a low velocity, low $\mathrm{Vp} / \mathrm{Vs}$ ratio background $(\mathrm{Vp}<6.25 \mathrm{~km} / \mathrm{s}, 1.63-1.70)$ consisting of granitoids and clastic metasedimentary rocks.

The middle crust stretches down to a depth of $30 \mathrm{~km}$ in the NW and to about $35 \mathrm{~km}$ at the SE end of the profile. Velocities in the middle crust vary between 6.25 and $6.7 \mathrm{~km} / \mathrm{s}$. The highest velocities are found in the SE part of the profile. The lower crust is thin and rather homogeneous, with velocities $(6.95-7.45 \mathrm{~km} / \mathrm{s})$ and $\mathrm{Vp} / \mathrm{Vs}$ ratios typical for mafic granulites. At the NW end of the profile, the lower crust has two layers that show both the lowest and highest velocities in the lower crust. Upper mantle velocities $(\mathrm{Pn})$ are rather uniform $(8.16 \mathrm{~km} / \mathrm{s})$ except at the NW end of the profile where higher velocities $(8.34 \mathrm{~km} / \mathrm{s})$ are recorded.

In the eastern part of the CLGC, seismic velocities in the upper and middle crust are similar to those beneath the granitoid areas in central and southern Finland (HyvöNEn et al. 2007). The most complex structure in the crust is seen beneath the Kuusamo schist belt and Central Karelian craton confirming the previous studies of the area.

The Lapland rift was formed by the northwesterly movement of Central and Southern Lapland away from the Western and Central Karelia craton. The arrival of a plume head beneath Lapland triggered the formation of layered intrusions, initiated a continental spreading centre or a triple junction (Fig. 13; WKC, $\mathrm{CKC}+\mathrm{BP}$ and $\mathrm{CL}(=\mathrm{CLGC}+\mathrm{CLGB}))$ and resulted in large scale mafic underplating of the crust. We interpret the HUKKA 2007 profile to image a partly 
buried continental rift, which has been inverted during the Svecofennian orogenic episodes. The inverted paleo-rift structure is, however, the dominant crustal structure. It has structural features typical of rifts: inward dipping rift shoulders, undulating thickness of the middle crust, high velocity lower crust and a rather uniform crustal thickness of $48 \mathrm{~km}$. The rift shoulders are located south of SP P and below SP R. Mafic layered intrusions are formed at the rift shoulders. Metavolcanic and sedimentary rock formations characterize the central part of the rift. We conclude that the HUKKA 2007 profile images an oblique cross-section of an asymmetric rift that has formed via simple shear.

\section{Acknowledgments}

This study was funded by the Institute of Seismology of the University of Helsinki, Sodankylä Geophysical Observatory of the University of Oulu, the Academy of Finland (exchange visitor grant no. 121730 for Dr. T. Janik) and the Finnish Academy of Sciences and Letters (visitor grant for Dr. T. Janik). We thank Dr. Kari Moisio for his support in the field work.

Open Access This article is distributed under the terms of the Creative Commons Attribution License which permits any use, distribution, and reproduction in any medium, provided the original author(s) and the source are credited.

\section{REFERENCES}

Ahtonen, N., HöltтÄ, P. and Huhma, H. (2007), Intracratonic Palaeoproterozoic granitoids in northern Finland: prolonged and episodic crustal melting events revealed by $\mathrm{Nd}$ isotopes and $\mathrm{U}-\mathrm{Pb}$ ages on zircon, Bulletin of the Geological Society of Finland 79(2), 143-174.

Airo, M-L (1999), Aeromagnetic and petrophysical investigations applied to tectonic analysis in the northern Fennoscandian Shield, Geological Survey of Finland, Report of Investigation 145, $51 \mathrm{p}$.

Amelin, Yu. V., Heaman, L. M. and Semenov, V. S. (1995), UPb geochronology of layered mafic intrusions in the eastern Baltic Shield; implications for the timing and duration of Paleoproterozoic continental rifting, Precambrian Research 75, 31-40.

Anttila, P. (Ed.), Ahokas, H., Front, K., Hinkkanen, H., Johansson, E., Paulamäki, S., Riekrola, R., Saari, J., Saksa, P., Snellman, M., Wikström and L., Öhberg, A. (1990), Final disposal of spent nuclear fuel in Finnish bedrock-Romuvaara site report, Posiva 99-11. Posiva Oy, Finland.
Behrendt, J.C., Green, A.G., Cannon, W.F., Hutchinson, D.R., Lee, M.W., Milkereit, B., Agena, W.F., and Spencer, C. (1988), Crustal structure of the Mid-Continent Rift Systemresults from GLIMPCE deep seismic reflection profiles, Geology $16,81-85$.

Berge, T.B. and Veal, S.L. (2005), Structure of the Alpine foreland, Tectonics 24, 1-10. doi:10.1029/2003TC001588.

Bogdanova, S.V., Gorbatschev, R., Grad, M., Janik, T., Guterch, A., Kozlovskaya, G., Motuza, G., Skridlaite, G., Starostenko, V., TARAN, L., and EUROBRIDGE and POLONAISE Working Groups (2006), EUROBRIDGE: new insight into the geodynamic evolution of the East European Craton, Geological Society, London, Memoirs. 32, 599-625.

BRADLEY, D.C. (2011), Secular trends in the geologic record and the supercontinent cycle, Earth-Science Reviews, 108, 16-33, and Supplementary Data, in electronic format, 17 p. doi:10.1016/ j.earscirev.2011.05.003.

ČERVENÝ, V. and PšEnčíK, I. (1983), SEIS83-numerical modelling of seismic wave fields in 2-D laterally varying layered structure by the ray method, In Documentation of Earthquake Algorithm, World Data Centre A for Solid Earth Geophysics (ed. EnGDAHL, E.R.) Boulder, Re. SE-35, 36-40.

Coffin, M.F. and Eldholm, O., (1993), Scratching the surface: estimating dimensions of large igneous provinces, Geology 21, 515-518.

Cook, F.A., Brown, L.D., Kaufman, S., Oliver, JE and Petersen, TA. (1981), COCORP seismic profiling of the Appalachian orogen beneath the Coastal Plain of Georgia, Geological Society of America Bulletin 92, 738-748. doi:10.1130/00167606.

Daly, J. S., Balagansky, V. V., Timmerman, M. J., and WhiteHousE, M. J. (2006), The Lapland-Kola orogen: Palaeoproterozoic collision and accretion of the northern Fennoscandian lithosphere, In European Lithosphere Dynamics (eds. Gee, D.G., and Stephenson, R. A.), Geological Society, London, Memoirs 32, pp. 579-598.

ERnst, R.E. and Buchan, K.L. (2001), Large mafic magmatic events through time and links to mantle plume-heads, pp. 483575. Chapter 19 in R.E. ERnst and K.L. Buchan (eds.) Mantle Plumes: Their Identification Through Time, Geological Society of America Special Paper 352.

Evins, P., M., Mansfeld, J. and LaAjoki, K., (2002), Geology and geochronology of the Suomujärvi Complex: a new Archaean gneiss region in the NE Baltic Shield, Finland, Precambrian Research 116, 3-4, 285-306.

GaÁl, G., Berthelsen, A., Gorbatschev, R., Kesola, R., Lehtonen, M., Marker, M. and RAASE, P. (1989), Structure and composition of the Precambrian crust along the POLAR profile in the northern Baltic Shield, Tectonophysics 162, 1-25.

Gorbatschev, R. and Bogdanova, S. (1993), Frontiers in the Baltic Shield, Precambrian Research 64, 3-21.

Grad, M. and Luosto, U. (1987), Seismic models of the crust of the Baltic Shield along the SVEKA profile in Finland, Annales Geophysicae 5B, 639-650.

Grad, M., TilRa, T. and ESC Working Group, (2009), The Moho depth map of the European Plate, Geophys. J. Int. 176, 279-292. doi:10.1111/j.1365-246X.2008.03919.x.

Guggisberg, B., Kaminski, W. and Prodehl, C. (1991), Crustal structure of the Fennoscandian Shield: A traveltime interpretation of the long-range FENNOLORA seismic refraction profile, Tectonophysics 195, 105-137. 
Hanski, E. and Huhma, H. (2005), Central Lapland Greenstone Belt. In: Lehtinen, M., Nurmi, P.A. and Ramo, O.T. (eds.), Precambrian Geology of Finland: Key to the evolution of the Fennoscandian Shield. Developments in Precambrian Geology 14, Amsterdam, Elsevier Science, pp. 139-193.

Heaman, L. (1997), Global mafic magmatism at 2.45 Ga: Remnants of an ancient large igneous province? Geology 25, 299-302.

Huhma, H., Cliff, R.A., Perttunen, V., Sakko, M., 1990. Sm-Nd and $\mathrm{Pb}$ isotopic study of mafic rocks associated with early Proterozoic continental rifting: the Peräpohja schist belt in northern Finland, Contrib. Mineral. Petrol. 104, 369-379.

Hyvönen, T., Tiira, T., Korja, A., Heikkinen, P., Rautioaho, E. and SVEKALAPKO SeIsmic Tomography Working Group (2007), A tomographic crustal velocity model of the central Fennoscandian shield, Geophysical Journal International 168, 1210-1226.

Hölttä, P., Balagansky, V., Garde, A.A., Mertanen, S., PeltoNen, P., Slabunov, A., Sorjonen-Ward, P. and Whitehouse, M. (2008), Archean of Greenland and Fennoscandia, Episodes 31 (1), 13-19.

Janik T., Kozlovskaya, E., Heikrinen, P., Yliniemi, J. and SilVENNOINEN, H. (2009), Evidence for preservation of crustal root beneath the Proterozoic Lapland-Kola orogen in the northern Fennoscandian shield derived from $P$ - and $S$ - wave velocity models of POLAR and HUKKA wide-angle reflection and refraction profiles and FIRE4 reflection transect, J. Geophys. Res. 114, B06308, doi:10.1029/2008JB005689.

Janik, T., Kozlovskaya, E. and Yliniemi, J. (2007), Crust-mantle boundary in the central Fennoscandian shield: constraints from wide-angle $P$ - and $S$-wave velocity models and new results of reflection profiling in Finland, J. Geophys. Res. 112, B04302, doi:10.1029/2006JB004681.

Janik, T., Yliniemi, J., Grad, M., Thybo, H., TilRa, T. and POLONAISE P2 Working GRoup 1 (2002), Crustal structure across the TESZ along POLONAISE'97 seismic profile P2 in NW Poland. Tectonophysics 360, 1-4, 129-152.

Keranen, K., Klemperer, S.L., Gloaguen, R. and The EAgle Working Group (2004), Three-dimensional seismic imaging of a protoridge axis in the Main Ethiopian rift, Geology 32, 949-952.

Kern, H., Walther, CH., Flüh, E.R. and Marker, M. (1993), Seismic properties of rocks exposed in the POLAR profile region-constraints on the interpretation of the refraction data, Precambrian Research 64, 169-187.

Korja, A. and HeikKinen, P.J. (2008), Seismic images of Paleoproterozoic microplate boundaries in Fennoscandian Shield. Chapter 11. In Condie, K.C, and Pease, V. (eds), When Did Plate Tectonics Begin on Planet Earth? Geological Society of America Special Paper 440, pp. 229-248, doi:10.1130/2008.2440(11).

Korja, A., Korja, T., Luosto, U. and Heikkinen, P. (1993), Seismic and geoelectric evidence for collisional and extensional events in the Fennoscandian Schield-implications for Precambrian crustal evolution, Tectonophysics 219, 129-152.

Korja, A., Lahtinen, R. and Nironen, M. (2006), The Svecofennian Orogen: a collage of microcontinents and island arcs. In: D. GEe, R. StePhenson (eds) European Lithosphere Dynamics, Geological Society, London, Memoirs 32, 561-578.

Korsman, K., Koistinen, T., Kohonen, J., Wennerström, M., EKdahl, E., Honkamo, M., Idman, H. and PekKala, Y. (Eds.), (1997), Suomen kallioperäkartta-Berggrundskarta över Finland-Bedrock map of Finland 1:1000 000. Geol. Surv. Finland, Espoo, Finland.
Kozlovskaya, E., Kosarev, G., Aleshin, I., Riznichenko, O. and Sanina, I. (2008), Structure and composition of the crust and upper mantle of the Archean-Proterozoic boundary in the Fennoscandian Shield obtained by joint inversion of receiver function and surface wave phase velocity of recording of the SVEKALAPKO array, Geoph. J. Int. 175, 135-152.

KukKonen, I.T., Heikkinen, P., Ekdahl, E., Huelt, S.-E., Yliniemi, J., Jalkanen, E. and FIRE Working Group (2006), Acquisition and geophysical characteristics of reflection seismic data on FIRE transects, Fennoscandian Shield. In: KuKKonen, I.T. and Lahtinen, R. (Eds.). Finnish Reflection Experiment FIRE 2001-2005, Geological Survey of Finland, Special Paper 43, $13-43$.

KuszNIR, N.J. and PARK, R.G. (1987), The extensional strength of the continental lithosphere: Its dependence on geothermal gradient, and crustal composition and thickness, in Continental Extension Tectonics, edited by M.P. CowARD et al., Geol. Soc. Spec. Publ. London, 28, 35-52.

Lahtinen, R., Garde, A.A. and Melezhik, V.A. (2008), Paleoproterozoic evolution of Fennoscandia and Greenland, Episodes $31,1,1-9$.

Lahtinen, R., Korja, A. and Nironen, M. (2005), Palaeoproterozoic tectonic evolution of the Fennoscandian Shield - a plate tectonic model. In: Lehtinen, M., Nurmi, P.A. \& Ramo, O.T. (Eds.), The Precambrian Bedrock of Finland: Key to the Evolution of the Fennoscandian Shield. Development in Precambrian geology, 14, Amsterdam, Elsevier Science, pp. 481-531.

Lister, G.S., Etheridge, M.A. and Symonds, P.A. (1986), Detachment faulting and the evolution of passive continental margins, Geology 14, 246-250.

Luosto, U., FlüH, E.R., Lund, C.-E. and POLAR WORKING GROUP (1989), The crustal structure along the POLAR Profile from seismic refraction investigation, Tectonophysics 162, $51-85$.

Luosto, U., Tirka, T., Korhonen, H., Azbel, I., Burmin, V., Buyanov, A., Kosminskaya, I., Ionkis, V. and Sharov, N. (1990), Crust and upper mantle structure along the DSS BALTIC profile in se Finland, Geoph. J. Int. 101, 89-110.

Melezhiк, V.A. (2006), Multiple causes of Earth's earliest global glaciation, Terra Nova v. 18, 130-137.

Mints, M.V., Berzin, R.G., Andryushchenko, Yu.N., Zamozhnyaya, N.G., Zlobin, V.L., Konilov, A.N., StupaK, V.M. and Suleimanov, A.K. (2004a), The deep structure of the Karelia craton along geotraverse 1-EU, Geotectonics 38 (5), 10-25.

Mints, M.V., Berzin, R.G., Suleimanov, A.K., Zamozhnyaya, N.G., Stupak, V.M., Konilov, A.N., Zlobin, V.L. and Kaulina, T.V. (2004b), The deep structure of the Early Precambrian crust of the Karelia craton, southeastern Fennoscandian Shield: results of investigation along CMP profile $4 B$, Geotectonics 38 (2), 10-29.

Patison, N. L., Korja, A., Lahtinen, R., Ojala, V. J. and THE FIRE WORKING GROUP (2006), FIRE seismic reflection profiles 4, 4A and 4B: Insights into the crustal structure of northern Finland from Ranua to Näätämö. In Finnish Reflection Experiment (FIRE) 2001-2005 (eds. KuKKonen, I.T., and LaHTINEN, R.), Geological Survey of Finland (GTK), Special paper 43, pp. 161-222.

Peltonen, P., 2005, Ophiolites, in Lehtinen, M., Nurmi, P. and RÄмö, T., eds, The Precambrian Bedrock of Finland-Key to the 
evolution of the Fennoscandian Shield: Elsevier Science B.V, pp. 237-278.

READING, A.M. (2005), Investigating the deep structure of terranes and terrane boundaries: insights from earthquake seismic data. In: EDITOR? Terrane Processes at the Margins of Gondwana. Special Publication (246). Geological Society, London, London, UK, pp. 293-303. ISBN 1-86239-179-3.

Sharov, N.V. (1993), Lithosphere of the Baltic Shield Based on seismic data, Kola Research Centre RAN, pp. 144 (in Russian).

Silvennoinen, H. and Kozlovskaya, E. (2006), 3D structure and physical properties of the Kuhmo Greenstone Belt (eastern Finland): Constrains from gravity modeling and seismic data and implications for the tectonic setting, J. of Geodyn. 43, 358-373, doi:10.1016/j.jog.2006.09.018.

Silvennoinen, H., Kozlovskaya, E., Kissling, E., Kosarev, G. and POLENET/LAPNET Working Group (2012), Compilation of Moho boundary map for northern Fennoscandian shield. Geoph. J.Int., submitted.

Silvennoinen, H., Kozlovskaya, E., Yliniemi, J. and Tilra, T. (2010), Wide angle reflection and refraction seismic and gravimetric model of the upper crust in FIRE4 profile area, northern Finland, Geophysica 46, 21-46.

Slabunov, A. I., Lobach-Zhuchenko, S. B., Bibikova, E. V., Balagansky, V. V., Sorjonen-Ward, P., Volodichev, O. I., Shchipansky, A. A., Svetov, S. A., Chekulaev, V. P., Arestova,
N. A. and Stepanov, V. S. (2006), The Archean of the Baltic Shield : geology, geochronology, and geodynamic settings, Geotectonics 40(6), 409-433.

Sobolev, S.V. and BАвеYко, A.Y. (1994), Modeling of mineralogical composition, density and elastic wave velocities in anhydrous magmatic rocks, Surveys in geophysics 15, 515-544. SorJonen-Ward, P., Nironen, M. and LuUkKonen, E. (1997), Greenstone associations in Finland. In: De WIT, M. \& AshwaL, L. (EDS.) Greenstone belts. Oxford monographs on geology and geophysics 35, 677-698.

Środa, P. (1999), Modifications of software package ZPLOT by C. A. Zelt, Inst. Geophys. Pol. Acad. Sc., Warsaw.

Tussu, P. and Hunma, H. (2006), Evolution of migmatitic granulite complexes : implications from Lapland Granulite Belt, Part II : Isotopic dating, Bulletin of the Geological Society of Finland 78 (2), 143-175.

Turchenko, S.I. (1992), Precambri an metallogeny related to tectonics in the eastern part of the Baltic Shield, Precambrian Research 58,121-141.

Uski, M., TirRa, T., Grad, M. and Yliniemi, J. (2012), Crustal seismic structure and depth distribution of earthquakes in the Archean Kuusamo region, Fennoscandian Shield, Journal of Geodynamics 53, 61-80.

ZeLt, C.A. (1994), Software package ZPLOT, Bullard Laboratories, University of Cambridge. 